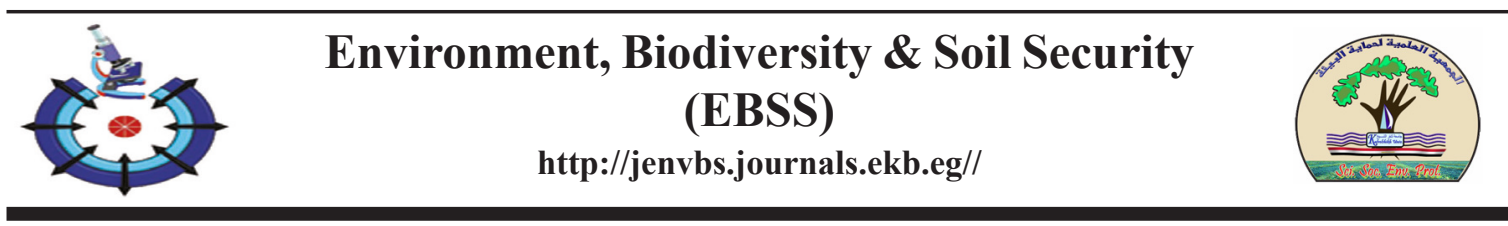

\title{
Effect of Irrigation Regime and Spraying Salicylic Acid on Characteristics and Quality of (Banzahir) Lime Fruits (Citrus aurantifolia B.) at Harvest, Marketing and Some Water Relations
}

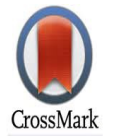

\author{
Ahmed H. A. Mansour ${ }^{1}$, R. Kh. Darwesh ${ }^{2 *}$ and Mohamed Hefzy ${ }^{2}$ \\ ${ }^{1}$ Horticultural Research Institute, Agricultural Research Center, Egypt \\ ${ }^{2}$ Soils, Water \& Environment, Research Institute (SWERI), Agricultural Research \\ Center, Egypt
}

\begin{abstract}
RRIGATION management is one of the most important factors for water saving, especially with limited water resources in Egypt. so, the present study was carried out during 2017 and 2018 on trees of Lime (Citrus aurantifolia), grown in sandy soil at Asyut Agriculture Research Station (ARC), Asyut Governorate, Egypt, to elucidate the effect of different irrigation regimes; $100 \%, 80 \%$ and $60 \%$ of ETc and spraying (SA); with and without spraying on yield, fruit quality and market ability; room temperature and cold temperature. The results can be summarized as follows: irrigation with $100 \%$ ETc and spraying SA recorded the highest values of Fruit length, fruit width, Fruit weight and Yield compared to the other irrigation regimes. While, irrigation with $60 \%$ ETc and spraying SA recorded the highest values of irrigation water productivity and economic water productivity in both seasons. Also, irrigation fruits with $100 \%$ ETc and treated with SA during growth season induced the highest level of Juice weight $\%$. Moreover, the obtained results indicated that irrigating fruits with $60 \%$ ETc and treating with SA decreased weight loss \% and decay $\%$ while, increased TSS $\%$, total acidity in fruit juice, and V.C content of mature fruit compared with the other treatments under marketability.
\end{abstract}

Keywords: Drip irrigation, Egyptian lime, Fruit quality, Marketability, Water productivity, Salicylic acid

\section{Introduction}

Citrus is one of the most important crops in the world next to grapes and apples. Egyptian lime (Citrus aurantifolia B) is one of the most communal fruit between citrus in Egypt, due to its high yield, fresh consumption, consumesd during the year, aromatic flavor and rising fruit quality. Egyptian lime trees; about 23228.11 hactar in Egypt, represent about $10.3 \%$ of total area of citrus (225717.91 ha) and produced about, 424204.1 ton representing about $10.35 \%$ of the total citrus production (4098590 tons) according to Ministry of Agriculture and Land Reclamation statistics (2015).
In Egypt, water is the most significant factor in agricultural output. Almost vegetarian production is mainly dependent upon irrigation. The Nile River is the main source of water from the limited water resources in Egypt. Under the limited the water resources in Egypt, we should do our best towards the management of irrigation water well on the farm level. The present share of water in Egypt is less than $1000 \mathrm{~m}^{3} /$ capital/year equivalent to the international standards of water poverty limit (ELQuosy, 1998) Deficit irrigation strategies can enhance water-use efficiency and saving the agro-ecosystems. Irrigation can also have great effects on fruit quality and shelf life during harvest, packing house operations, storage, and

\footnotetext{
Corresponding author : Email: r_darwesh82@yahoo.com

Received: 25/10/2020; Accepted: 16/11/2020

DOI: 10.21608 /jenvbs.2020.47625.1110

(C)2020 National Information and Documentation Center (NIDOC)
} 
distribution. These include effect on fruit color, softness, juice content, and the physiological disorders (Ritenour et al. 2002). Kallsen et al. (2011) reported irrigation influence on fruit size, quality, total yield, and time of harvest. Water stress can affect yield and fruit quality. Water deficits have increased the concentration of juice and TSS, especially sugars, through shortterm fruit dehydration or longer-term osmotic adjustment (Perez-Perez et al. 2009). Salicylic acid (SA) (o-hydroxybenzoic acid), is one of a group of plant phenolics and distributed in plants. Salicylic acid is considered as a hormonelike substance, which plays a great role in the organization of plant growth and development Raskin (1992).

At the last 20 years, salicylic acid has drawn the attention of researchers because it can encourage systemic obtained resistance (SAR) in plants. Salicylic acid has the ability to motivate plant defense systems against different biotic and abiotic stresses (Tiwari et al. 2017 and Koo et al. 2020). Salicylic acid (SA) represents a plant messenger that induces the plant tolerance against biotic and abiotic stresses (Horvath et al. 2007). It has various effects on adaptation of stress and plant damage depending on the plant species, its concentration, and the applied method of SA (Metwally et al. 2003). Earlier reports showed that the exogenous application of SA can ameliorate the drought stress impact in various plant species (Arfan et al. 2007), and the plant water deficit (Bezrukova et al. 2001). Pre- and post-harvest SA treatments were found to reduce the fruits decay and the chilling injury, and improve the fruits quality, appearance, texture, and the nutritional values (Asghari and Aghdam, 2010; Glowacz and Ree, 2015). Researchers applied SA as postharvest treatments "Kinnow" mandarin (Haider et al. 2020), mango fruits (Gonchikari Lokesh et al. 2020), and murcott mandarin (Ennab et al. 2020) for increasing the quality.

Therefore, the target of the present study is to determine the effect of irrigation regime and application of SA on the yield, quality and marketability of Egyptian lime under water deficiency conditions.

\section{Materials and Materials}

\section{Experimental site}

The experiments were conducted at the Experimental Farm of Arab El-Awammer Research Station (latitude $27^{\circ}, 03^{\prime} \mathrm{N}$, longitude $31^{\circ}, 01^{\prime} \mathrm{E}$ and $71 \mathrm{~m}$ above sea level), Agricultural Research Center (ARC), Asyut, Egypt. Physical and chemical characteristics of the experimental site are shown in Table 1. In addition, climatic data were obtained daily from a weather station in the experimental and it is presented in Table 2.

\section{Plant Materials}

The present study was carried out during years 2017 and 2018 on trees of Lime (Citrus aurantifolia), planted $4 \times 4$ metres, were 10 years old, irrigated with drip irrigation (one drip-line was used in each tree row with two drippers (16 $\mathrm{L} \mathrm{h}^{-1}$ ) per tree) to elucidate the effect of different irrigation regimes and spraying Salicylic (SA) acid on yield, fruit quality at harvest and marketing, Where the fruits were placed at room temperature and in the display refrigerator (cold temperature). Eighteen trees nearly similar in growth, healthy and subjected to the same cultural practices were selected and then divided into 6 treatments each has 3 replicates where each replicate has one tree.

The following treatments were during the growing season:

A. Main treatments (irrigation regimes)

1- Irrigation with amounts of water equal to $100 \%$ crop evapotranspiration (ETc).

2- Irrigation with amounts of water equal to $80 \%$ (ETc) and,

3 - Irrigation with amounts of water equal to $60 \%$ (ETc).

B. Sub main treatments 1- Sprayed salicylic acid (400 ppm) and, 2- Sprayed water tap (0 ppm salicylic acid)

The trees were sprayed three times at the first week of June, July and August. Trees under study were sprayed in early morning using a back gun sprayer 20 liters until solution run off. The fruits were harvested in mid-August manually and carefully brought shortly after harvest, to the Agricultural Research Station laboratory. At the beginning of the harvesting, samples of 3 replicates from each treatment were taken to determine the initial characteristics, Then I took a quantity of fruits divided into two parts, the first section for fruits at room temperature and the second section for cold temperatures, and each section is divided into two groups, the first group to measure weight loss and the percentage of decay fruits while the second one was devoted juice and the chemical analysis. 
TABLE 1. Chemical and physical characteristics for experimental site

\begin{tabular}{|c|c|c|c|c|c|c|c|c|c|c|}
\hline \multicolumn{11}{|c|}{ Chemical properties } \\
\hline \multirow{2}{*}{$\begin{array}{c}\text { pH } \\
(1: 1)\end{array}$} & \multirow{2}{*}{$\begin{array}{c}\text { EC } \\
\text { dS m } \text { m }^{-1} \\
(1: 1)\end{array}$} & \multicolumn{4}{|c|}{ Soluble cations $\left(\mathrm{mmol}_{\mathrm{c}} \mathrm{l}^{-1}\right)$} & \multicolumn{3}{|c|}{ Soluble anions $\left(\operatorname{mmol}_{c} \mathbf{l}^{-1}\right)$} & \multirow{2}{*}{$\begin{array}{c}\text { Available P } \\
\left(\mathrm{mg} \mathrm{kg}^{-1}\right)\end{array}$} & \multirow{2}{*}{$\begin{array}{c}\text { Total N } \\
(\%)\end{array}$} \\
\hline & & $\mathrm{Ca}^{++}$ & $\mathrm{Mg}^{++}$ & $\mathrm{Na}^{+}$ & $\mathrm{K}^{+}$ & $\mathrm{CO}_{3}^{--}$ & $\mathrm{HCO}_{3}^{--}$ & $\mathrm{Cl}^{-}$ & & \\
\hline 8.37 & 0.33 & 1.43 & 1.16 & 0.19 & 0.75 & 0.0 & 1.68 & 1.47 & 8.31 & 0.009 \\
\hline \multicolumn{11}{|c|}{ Physical properties } \\
\hline \multicolumn{3}{|c|}{$\begin{array}{c}\text { Particle size distribution } \\
(\%)\end{array}$} & Texture & \multicolumn{4}{|c|}{ Moisture content (as volume \%) } & \multirow{2}{*}{$\begin{array}{c}\text { O.M } \\
(\mathrm{g} \mathrm{kg-1})\end{array}$} & \multirow{2}{*}{$\mathrm{CaCO}_{3}(\%)$} & \multirow{2}{*}{$\begin{array}{c}\text { Bulk } \\
\text { density } \\
\left(\mathrm{g} \mathrm{cm}^{-3}\right)\end{array}$} \\
\hline Sand & Silt & Clay & class & S. P. & F.C. & & $\mathbf{P}$. & & & \\
\hline 89.9 & 7.1 & 3.0 & Sandy & 23.3 & 10.9 & & 5 & 1.9 & 309 & 1.63 \\
\hline
\end{tabular}

TABLE 2. Average monthly meteorological data of Assiut weather station during two years (2017 and 2018)

\begin{tabular}{|c|c|c|c|c|c|c|c|}
\hline Year & Month & $\begin{array}{c}T \max \\
\left({ }^{\circ} \mathrm{C}\right)\end{array}$ & $\begin{array}{c}\mathrm{T} \text { min } \\
\left({ }^{\circ} \mathrm{C}\right)\end{array}$ & $\begin{array}{c}\text { RH } \\
\%\end{array}$ & w.s / km/h & Sunshine & ETo (mm/day) \\
\hline \multirow{12}{*}{2017} & January & 19.3 & 5.3 & 55.3 & 14.8 & 8.9 & 3.73 \\
\hline & February & 20.5 & 6.3 & 52.6 & 14.5 & 9.7 & 4.33 \\
\hline & March & 25.3 & 11 & 42.5 & 17.2 & 9.9 & 6.44 \\
\hline & April & 31.3 & 15.5 & 36.6 & 17.3 & 10.3 & 8.59 \\
\hline & May & 36.3 & 20 & 31.4 & 16.2 & 11.4 & 10.29 \\
\hline & June & 37.4 & 23.4 & 34.6 & 21 & 12.3 & 11.77 \\
\hline & July & 39.1 & 25.3 & 32.7 & 16.3 & 12.2 & 11.11 \\
\hline & August & 37.8 & 24.6 & 38.8 & 17.6 & 11.9 & 10.50 \\
\hline & September & 35.3 & 20.9 & 44.6 & 20.7 & 10.8 & 9.50 \\
\hline & October & 30.3 & 16.5 & 47 & 17.2 & 10.0 & 6.94 \\
\hline & November & 25.1 & 10.9 & 54.6 & 15.2 & 9.4 & 4.75 \\
\hline & December & 23.2 & 9 & 58.8 & 14.6 & 9.0 & 3.98 \\
\hline \multirow{12}{*}{2018} & January & 19.9 & 6.5 & 57.4 & 15.3 & 8.9 & 3.77 \\
\hline & February & 26.1 & 11.2 & 44.3 & 14.4 & 9.7 & 5.63 \\
\hline & March & 30.5 & 14.2 & 36.2 & 16.9 & 9.9 & 7.90 \\
\hline & April & 32.4 & 16.6 & 36.2 & 18.4 & 10.3 & 10.93 \\
\hline & May & 37.7 & 21.7 & 29.2 & 17.5 & 11.4 & 11.13 \\
\hline & June & 38.5 & 23.2 & 33.6 & 20 & 12.3 & 11.90 \\
\hline & July & 38 & 24.7 & 41.5 & 18.7 & 12.2 & 10.84 \\
\hline & August & 37.6 & 24.3 & 40.7 & 19.8 & 11.9 & 10.81 \\
\hline & September & 35.5 & 22 & 46.2 & 20.5 & 10.8 & 9.43 \\
\hline & October & 32.6 & 18.9 & 46.5 & 18.1 & 10.0 & 7.58 \\
\hline & November & 26.5 & 13.1 & 53.8 & 14.7 & 9.4 & 4.93 \\
\hline & December & 20.8 & 8 & 62.8 & 16.3 & 9.0 & 3.62 \\
\hline
\end{tabular}

$\mathbf{T} \mathbf{M a x}=$ Maximum temperature $\left({ }^{\circ} \mathrm{C}\right) \mathbf{T} \mathbf{m i n}=$ Minimum temperature $\left({ }^{\circ} \mathrm{C}\right) \mathbf{R H}=$ Relative humidity $(\%) \mathbf{W} . \mathbf{S}=$ Wind speed $(\mathrm{Km} / \mathrm{h})$ $\mathbf{E T o}=$ Reference evapotranspiration. 
All were fruits selected without any decay and, fruits were washed with tap water. Thereafter, air dried under room temperature. Each fruit was packed using perforated bag and weighted. Fruits were stored in two different temperatures, room temperature at $28^{\circ} \mathrm{C} \pm 2$ and $50-65 \%$ relative humidity) and cold temperature $\left(7^{\circ} \mathrm{C} \pm 2\right.$ and $70-85 \%$ relative humidity). Fruits kept at room temperature were examined every 2 days but under cold temperature conditions, the samples were examined every 4 days to study the change in Fruits and Fruits characteristics through marketing.

Irrigation-water measurements and crop-water relations

Crop evapotranspiration (ETc)

CROPWAT model was used to calculate reference evapotranspiration according to Penman Monteith.

Crop evapotranspiration (ETc) was calculated according to (Allen et al. 1998)

$$
E T_{c}=E T_{\mathrm{o}} \times K c
$$

Where:

$\mathrm{ETc}=$ Crop evapotranspiration.

$\mathrm{ET}_{0}=$ Reference evapotranspiration, and

$\mathrm{Kc}=$ Crop coefficient (from FAO paper 56)

\section{Irrigation applied water}

The amounts of actual irrigation applied water under each irrigation treatment were determined using the following equation: James (1988)

Where: $\quad I \cdot R a=\frac{E T c+L f}{E r}$

I. $\mathrm{Ra}=$ total actual irrigation applied water $\mathrm{mm} /$ interval.

$\mathrm{ETc}=$ Crop evapotranspiration

$\mathrm{Lf}=$ leaching factor $10 \%$, and

$\mathrm{Er}=$ irrigation system efficiency.

\section{Productivity of irrigation water}

The productivity of irrigation water (PIW, kg/ $\mathrm{m}^{3}$ ) values were calculated according to Ali et al (2007) as follows :

$$
\text { Where : } \quad P I W=\frac{Y}{I}
$$

$\mathrm{PIW}=$ productivity of irrigation water $\left(\mathrm{Kg} \mathrm{m}^{-3}\right)$, $\mathrm{Y}=$ yield $\mathrm{kg} \mathrm{ha}^{-1}$, and

$\mathrm{I}=$ irrigation applied water, $\mathrm{m}^{3} \mathrm{ha}^{-1}$ (Irrigation water + effective rainfall)

Note: effective rainfall $=$ rianfall $* 0.7$ (Novica, 1979).

Env. Biodiv. Soil Security Vol. 4 (2020)
Economic productivity of irrigation water

Irrigation productivity of irrigation water can be expressed as economical productivity (EPIW) and (EWP) according to Molden (1997). It was calculated as follows:

$$
E P I W=\frac{\text { Gross value of product }\left(L . E \cdot h a^{-1}\right.}{\text { Total amount of irrigation applied water }\left(\mathrm{m}^{3} \mathrm{ha}\right)}
$$

\section{Measurements}

\section{Fruit weight loss}

Fruit weight loss was calculated according to the equation as follows:

Fruit weight loss $\%=($ Initial Fruit weightFinal Fruit weight / Initial Fruit weight) x 100

Decay

Decay rate was calculated according to the equation as follows:

$$
\begin{gathered}
\text { Fruit decay } \%=(\text { Weight of decayed Fruit / } \\
\text { Initial Fruit weight }) \times 100
\end{gathered}
$$

Juice weight percentage/fruit

Juice weight was calculated according to the equation as follows:

$$
\begin{gathered}
\text { Juice weight } \%=(\text { Juice weight } / \text { fruit weight }) \\
\text { x } 100
\end{gathered}
$$

\section{Total soluble solids}

Total soluble solids (TSS\%) were determined using hand refractometer.

\section{Titratable acidity}

Acidity of the fruit juice was determined by titration of $5 \mathrm{ml}$ juice against $0.3 \mathrm{~N}$ sodium hydroxide using phenolphthaline as an indicator. Titratable acidity was expressed as grams of citric acid per $100 \mathrm{ml}$ fruit juice according to the A.O.A.C. (1985).

Total soluble solids/acidity ratio (TSS/Acid ratio)

TSS/acid ratio was calculated by dividing TSS $\%$ by total acidity $\%$ in fruit juice.

\section{Ascorbic acid (V.C.) content}

The vitamin "C" content was determined, in fruit juice during cold storage titration with, 2,6-Dichlorophenol indophenol blue dye. According to the A.O.A.C. (1985), and expressed as $\mathrm{mg}$ of ascorbic acid/100 $\mathrm{g}$ juice. 


\section{Statistical analysis}

In the field experiment : irrigation regimes treatments were three whole plots while the spraying Salicylic acid (SA) were considered as splits. This experiment was conducted in splitplot with three replicate, one bag each. The field treatments were six whole plots $(\mathrm{T})$, while the storage periods were considered as splits (P). All recorded data were tabulated and statistically analyzed according to Snedecor and Cochran (1990) using new L.S.D. at the level of 0.05 in comparison between various treatment means.

\section{Results and Discussion}

\section{Irrigation water relations}

Crop evapotranspiration

Data in Fig. 1, show the values of the crop evapotranspiration (ETc) calculated according to Penman Monteith equations for trees of Lime during the two years (2017 and 2018). Results showed that the total values of ETc were 2264.82 $\mathrm{mm}$ during year 2017 and were $2423.32 \mathrm{~mm}$ during year 2018. The results also indicated that the total ETc values in the second year were higher than the values of the first year. This difference may be due to low air temperature (mean air temperature in the year 2017 was $15.7^{\circ} \mathrm{C}$ minimum and $30.1^{\circ} \mathrm{C}$ maximum) and wind speed (mean wind speed in the year 2017 was16.9 $\mathrm{Km} / \mathrm{h}$ ) in the first year compared to the second year (mean air temperature in the year 2018 were $17.0{ }^{\circ} \mathrm{C}$ minimum and $31.3^{\circ} \mathrm{C}$ maximum and mean wind speed in the year 2018 was 117.6 $\mathrm{Km} / \mathrm{h}$ ). The maximum crop evapotranspiration was in June this is due to increase the reference evapotranspiration during this month compared to the other months in the year. These results are in the same line with those reported by Al- Naeem (2014), Zaghloul and Moursi (2017), Silva et al. (2019) and Jamshidi et al. (2020).

\section{Irrigation applied water $\left(\mathrm{m}^{3} / \mathrm{ha}\right)$}

The monthly irrigation applied water for lime trees were presented in Fig. 2. The data showed that, the values of irrigation applied water for lime trees were greatly affected by irrigation regimes (100, 80 and 60\% ETc). The irrigation applied water was found to be 27681, 22144 and $13286 \mathrm{~m}^{3} / \mathrm{ha}$. in the first year (2017) for $100 \%$, 80 and $60 \%$ ETc, respectively, and were 29618 , 23694 and $14216 \mathrm{~m}^{3} \mathrm{ha}^{-1}$ in the second year (2018). The results also, indicated that the values of total irrigation applied water in the second year were higher than the values of the first year. This difference may be due to the increases air temperature and wind speed in the second year. These results agree with Amer (2020) on sugar beet and cotton.

The irrigation applied water varies from growth month to another through the two growth years. The irrigation applied water reached its peak in June. This may be due to the high reference evapotranspiration through this month. The seasonal level of irrigation applied water was mostly influenced by irrigation treatments. The increase in Irrigation applied water under 100\% ETc treatments may be attributed to the increase in direct evaporation. Therefore, the seasonal irrigation applied water is higher under 100\% followed by $80 \%$ and $60 \%$ ETc for lime trees during the two growth years. These results are in the same line with those reported by Zaghloul (2017), Silva et al. (2019) and Jamshidi et al. (2020).

\section{Productivity of irrigation water $\left(P I W \mathrm{~kg} / \mathrm{m}^{3}\right)$}

The data in Fig. 3 and 4, show the effects of irrigation regime and spraying salicylic acid on the productivity of irrigation water (PIW). PIW in agricultural production system is focused on producing more food with the same water resources or, producing the same amount of food with less water resources. PIW was significantly decreased when lime orchard was irrigated with $100 \%$ ETc compared to 80 and $60 \%$ ETc. The highest PIW ( 0.57 and $0.45 \mathrm{~kg} \mathrm{~m}^{3}$ ) in this study were produced by spraying salicylic acid under irrigated with $60 \%$ ETc. These results agree with those obtained by Zaghloul and Moursi (2017) reported that irrigation water use efficiency was decreased linearly due to increasing irrigation water (Darwesh, 2018; Aiad, 2019; and AbdelFattah et al. 2020).

Economic productivity of irrigation water (L.E. $\left.m^{-3}\right)$

Economic productivity of irrigation water in agricultural production system is focused on gross value of product, $\mathrm{L} \mathrm{E} \mathrm{m}^{-3}$. EPIW shows in Fig. 5 and 6 take the same liner of PIW, it was significantly decreased when lime orchard was irrigated with $100 \%$ ETc compared to 80 and $60 \%$ ETc. The highest EPIW, 7.73 and 4.29 LE $\mathrm{m}^{-3}$ in the first and second season respectively were produced by spraying salicylic acid under irrigated with $60 \%$ ETc. 


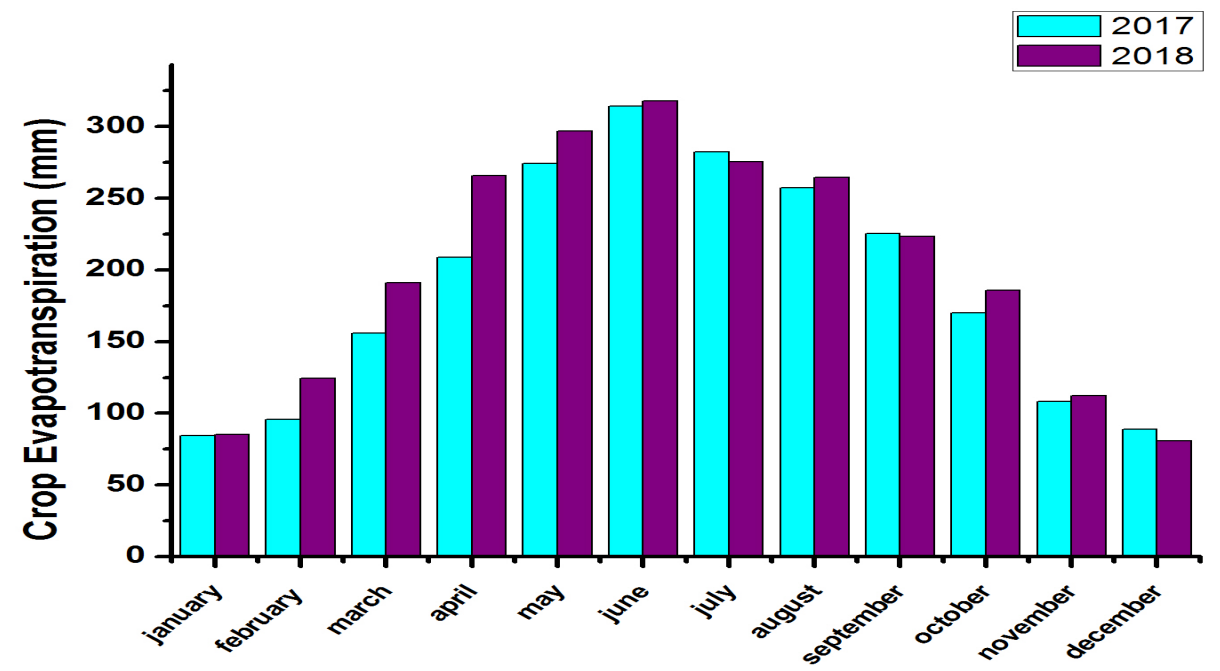

Fig. 1. Crop evapotranspiration ETc (mm) during years 2017 and 2018 of Lime trees calculated according to Penman Monteith equations
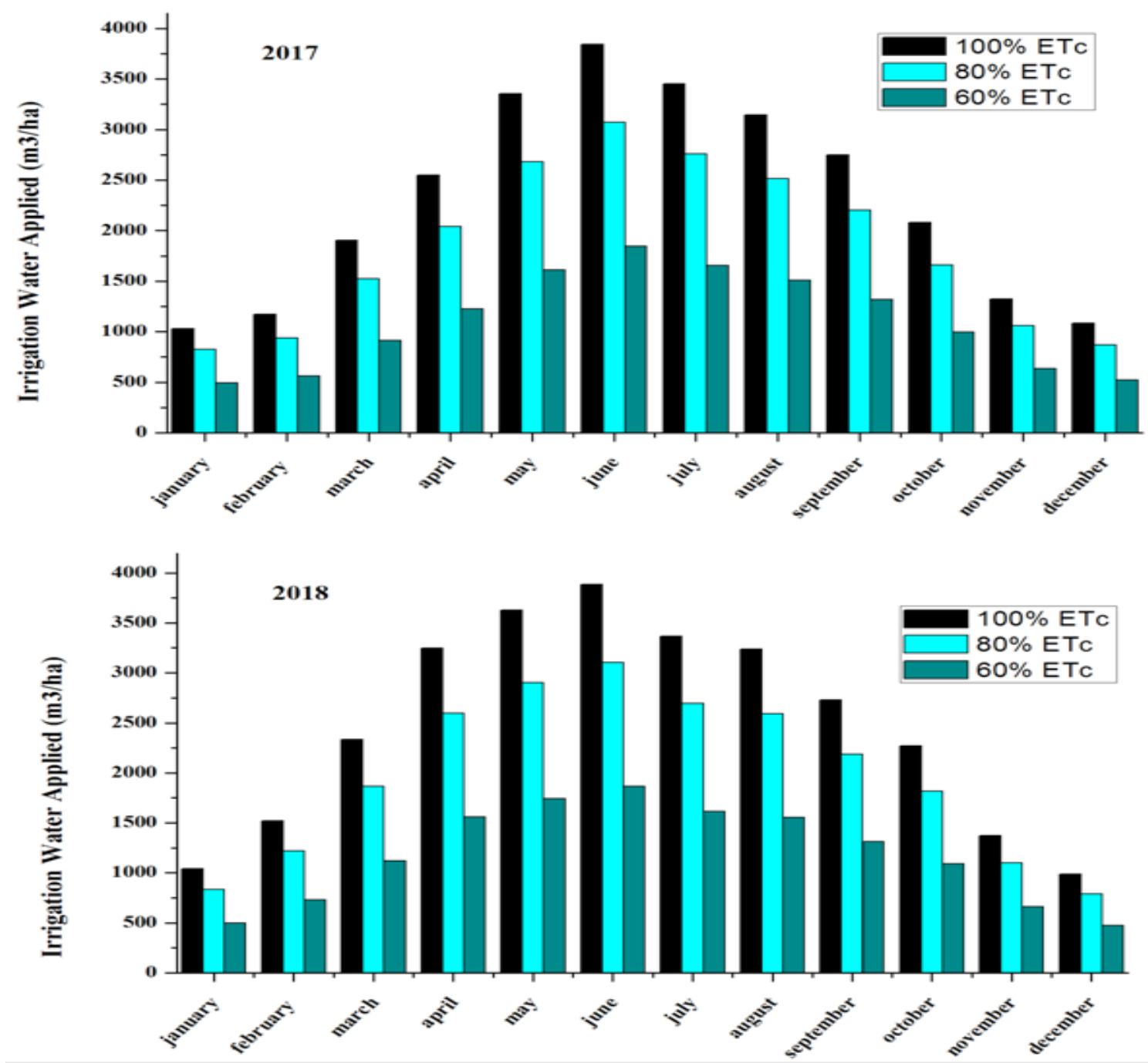

Fig. 2. Irrigation applied water $\left(\mathrm{m}^{3} / \mathrm{ha}\right)$ as affected by irrigation regime during years 2017 and 2018 Env. Biodiv. Soil Security Vol. 4 (2020) 


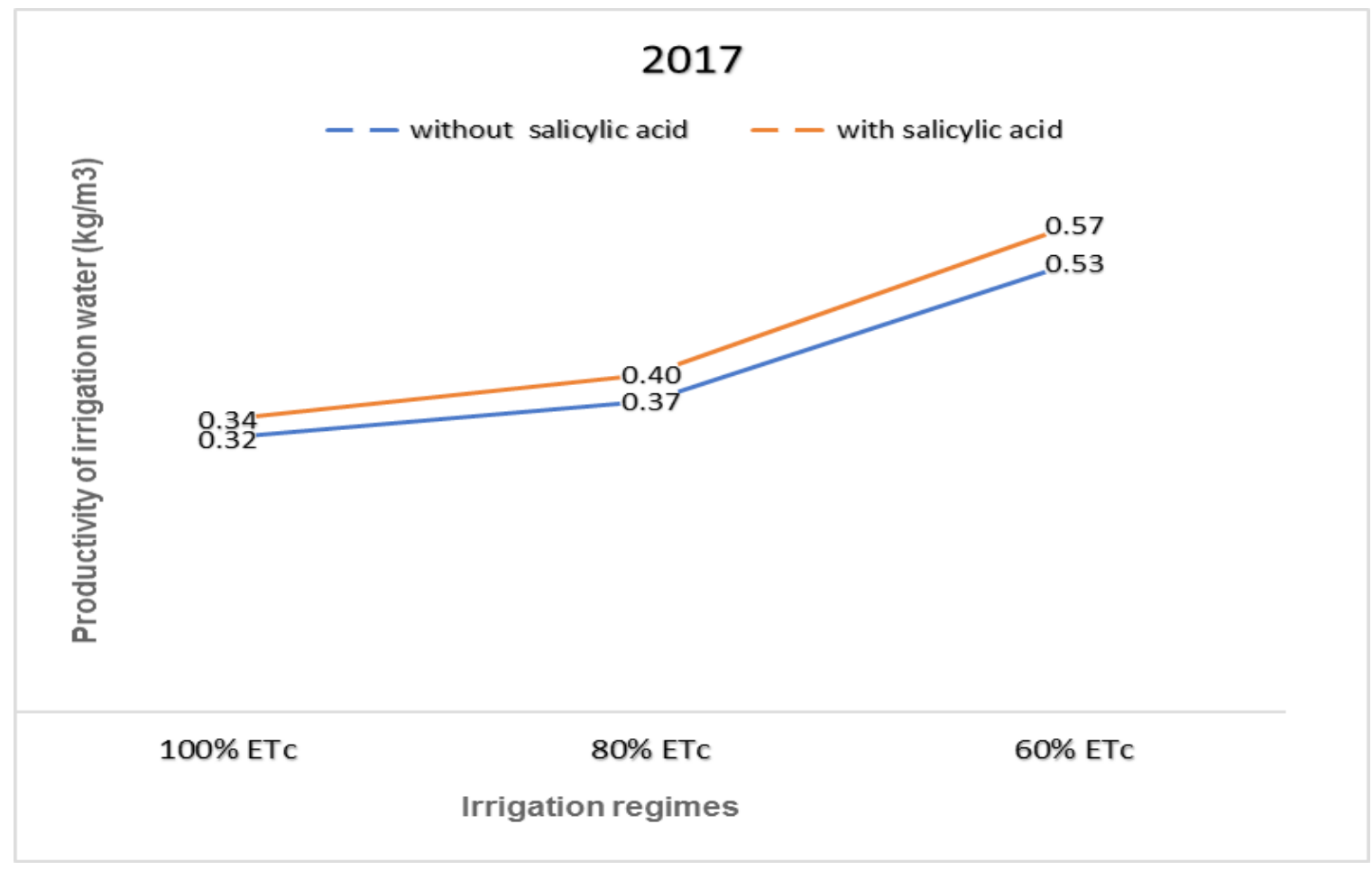

Fig. 3. Productivity of irrigation water $\mathrm{kgm}^{-3}$ of Lime fruit as influenced by irrigation regime and spraying Salicylic acid during 2017 year

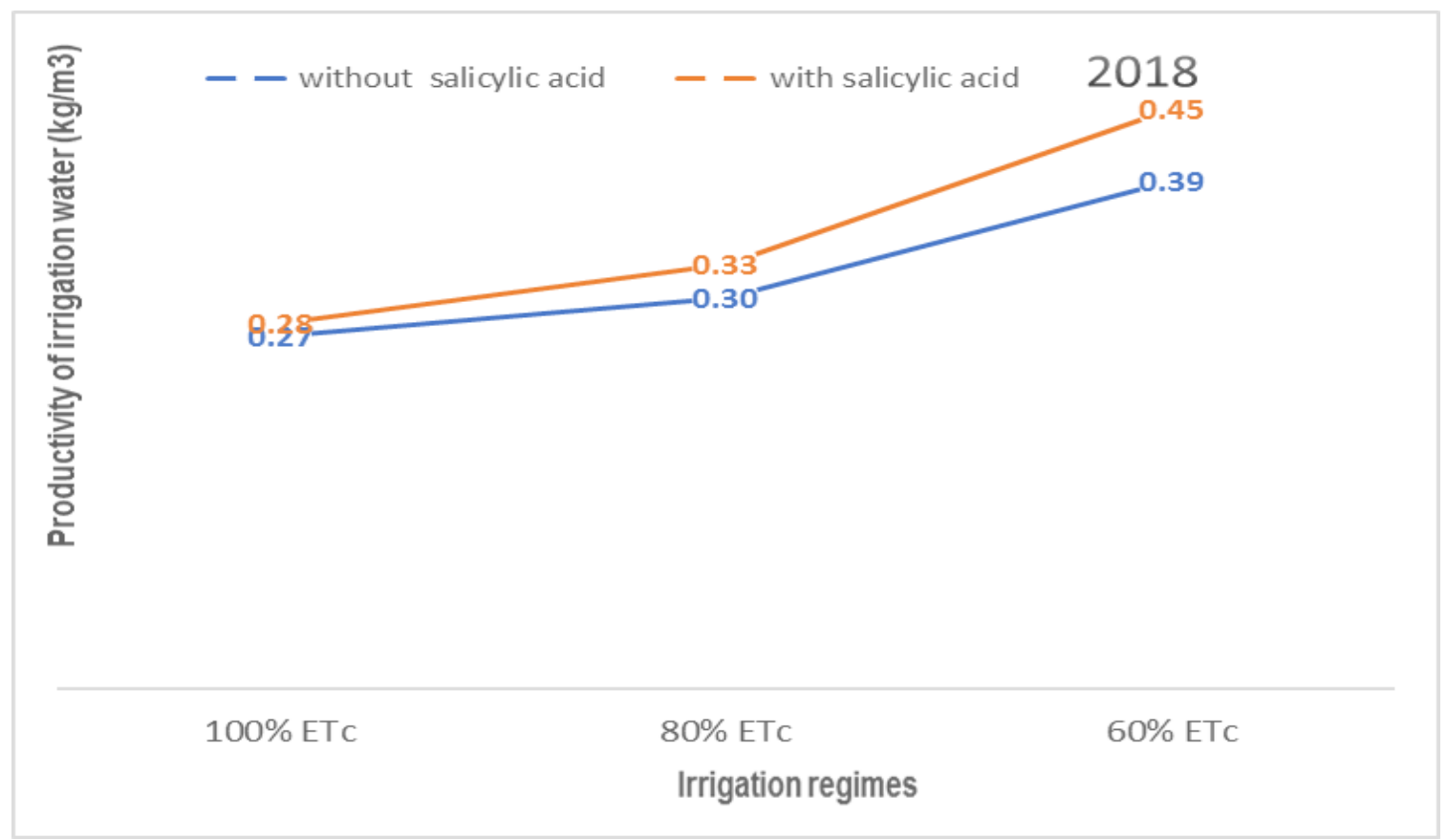

Fig. 4. Productivity of irrigation water $\mathrm{kgm}^{-3}$ of Lime fruit as influenced by irrigation regime and spraying Salicylic acid during 2018 year 


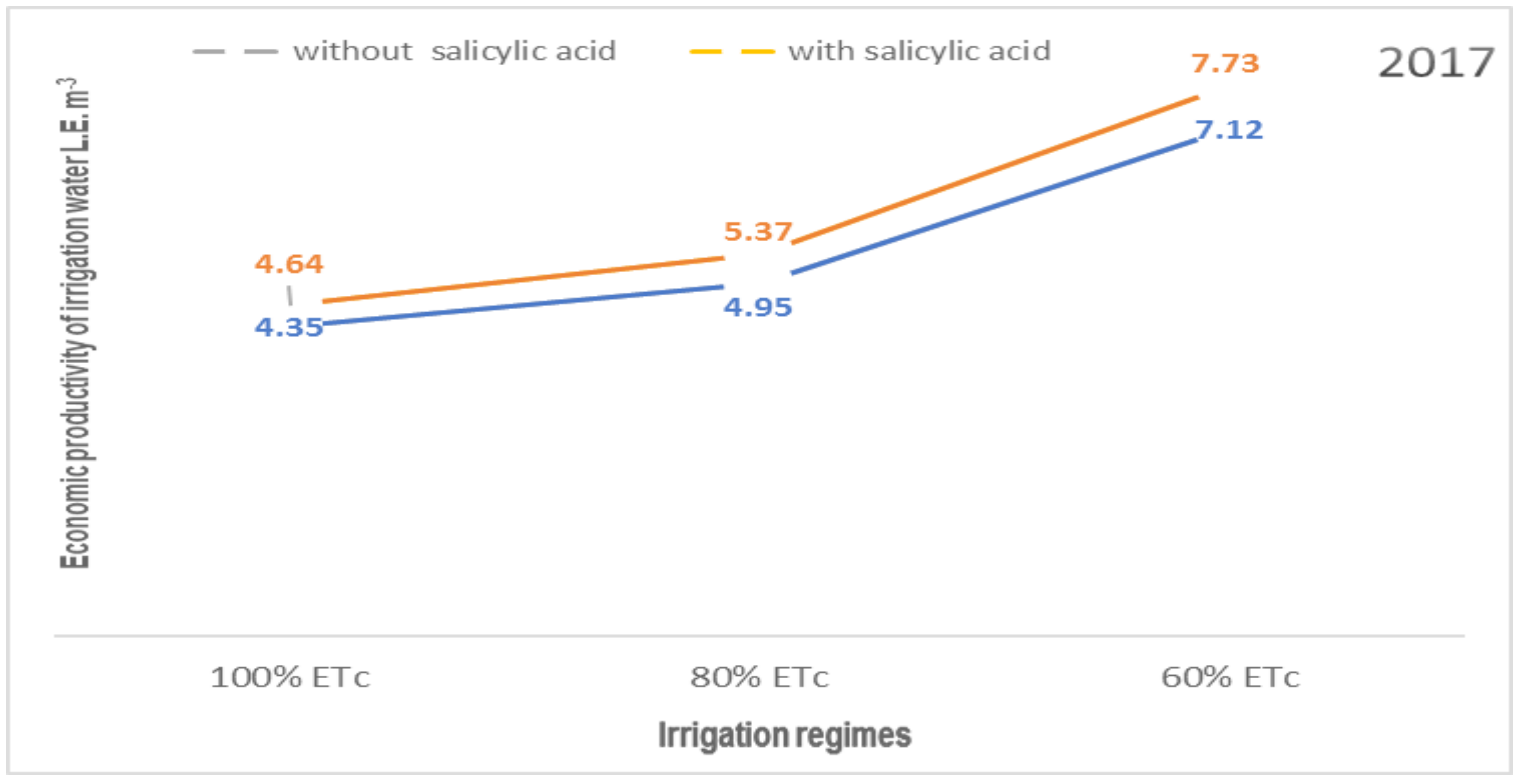

Fig. 5. Economic productivity of irrigation water $\mathrm{kgm}^{-3}$ of Lime fruit as influenced by irrigation regime and spraying Salicylic acid during 2017 year

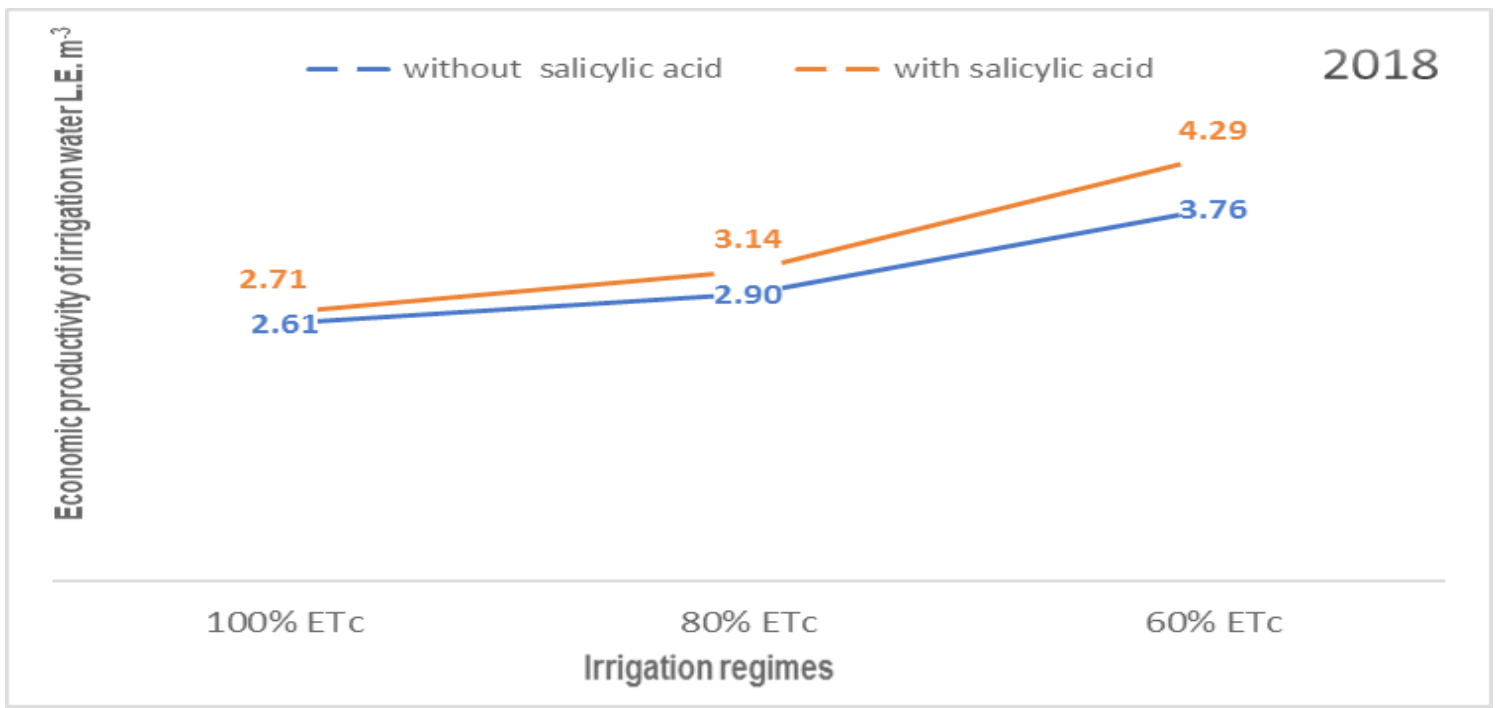

Fig. 6. Economic productivity of irrigation water $\mathrm{kgm}^{-3}$ of Lime fruit as influenced by irrigation regime and spraying Salicylic acid during 2018 year

Yield, yield components and quality of lime fruits at harvest

Data in in Table 3, cleared that the results of the two seasons took the similar data trend as following; the yield (Ton ha-1) was significantly affected by different irrigation water regime, fruit weight was gradually decreased by decreasing the irrigation in both seasons. Salicylic acid increasing the fruit weight compared to untreated. Fruit dimensions results indicated that length and diameter were significantly decreased by reducing irrigation regime and the smallest fruit were produced under deficit irrigation regime $60 \%$. Salicylic acid spraying has also significant increase effects on both the length and diameter of the fruit. Decreasing the irrigation regime from $100 \%$ to $80 \%$ and $60 \%$ induced increase in Reg weight \% from (51.93 to 53.20 and $58.45 \%$ ) in the first season and (51.80 to 55.20 and $57.40 \%$ ) in the second season, respectively. Salicylic acid spray caused an improvement in Reg weight \% (53.79and 54.33) compared to untreated fruits

Env. Biodiv. Soil Security Vol. 4 (2020) 
(55.27 and 55.27) in both seasons, respectively. The reduction in fruit weight and size under deficit soil moisture content could be due to reduce the fruit cell enlargement through reduce fruit trugor early in the season and to decrease cell water content (Li et al., 1989). Behbudian et al. (1994) pointed out that, reduce the fruit size under water stress might be due to less assimilate availability through decrease net photosynthesis rate $(\mathrm{Pn})$. These results are in the same line of Mikhael and Maddy (2007) on apple and Ibrahim and Abd El-Samad (2009) on pomegranate, and Magda - Khattab et al. (2011) on pomegranate which found a progressive reduction in fruit yield was observed in deficit irrigation treatment as compared to higher irrigation treatment. The increase in yield parameters due to salicylic acid observed in the present investigation can be attributed to increased photosynthetic activity in leaves and translocation of more photoassimilates to fruits. Salicylic acid is responsible for increasing yield by increasing fruit set percentage, increase in fruit weight and number of fruits per tree. It also stimulates cell division and the tolerance of plants to all stresses namely diseases, water and salt stresses and protects plant cells from oxidation by free radicals (Raskin, 1992; Lee et al. 1995; Shah, 2003). These findings agree with the findings of Ngullie et al. (2014) and Ahmed et al. (2015a) in mango, Ashraf et al. (2013) in kinnow, Rahmani (2017) on Mango and Amer et al. (2019).

TABLE 3. Effect of irrigation regime, spraying salicylic acid on Yield (Ton ha $\left.{ }^{-1}\right)$, Yield (kg tree $\left.{ }^{-1}\right)$, Fruit weight (g), Fruit length $\left(\mathrm{cm}^{2}\right)$, fruit width $\left(\mathrm{cm}^{2}\right)$ and Reg weight of lime fruits at harvest

\begin{tabular}{|c|c|c|c|c|c|c|}
\hline \multirow{2}{*}{$\begin{array}{l}\text { Irrigation (ETe) } \\
\text { Spraying }\end{array}$} & $100 \%$ & $80 \%$ & $60 \%$ & $100 \%$ & $80 \%$ & $60 \%$ \\
\hline & \multicolumn{3}{|c|}{2017} & \multicolumn{3}{|c|}{2018} \\
\hline \multicolumn{7}{|c|}{ Yield (Ton/ha) } \\
\hline non spraying SA & 8.9 & 8.1 & 7.0 & 8.1 & 7.2 & 5.6 \\
\hline spraying SA & 9.5 & 8.8 & 7.6 & 8.4 & 7.8 & 6.4 \\
\hline L.S.D. 0.05 & I; 0.43 & $\mathrm{SA} ; 0.42$ & I*SA; 0.72 & I;0.28 & $\mathrm{SA} ; 0.41$ & I*SA; 0.71 \\
\hline \multicolumn{7}{|l|}{ Yield (kg/tree) } \\
\hline non spraying SA & 14.2 & 13.0 & 11.3 & 12.9 & 7.2 & 8.9 \\
\hline spraying SA & 15.2 & 14.1 & 12.2 & 13.4 & 7.8 & 10.2 \\
\hline L.S.D. 0.05 & I; 0.56 & $\mathrm{SA} ; 0.29$ & I*SA; 0.49 & I; 0.53 & SA; 0.14 & I*SA; 0.26 \\
\hline \multicolumn{7}{|c|}{ Fruit weight (g) } \\
\hline non spraying SA & 30.17 & 27.87 & 27.87 & 27.87 & 26.66 & 23.72 \\
\hline spraying SA & 31.27 & 29.63 & 29.63 & 29.63 & 28.95 & 25.00 \\
\hline L.S.D. 0.05 & I; 0.83 & $\mathrm{SA} ; \mathbf{1 . 0 5}$ & I*SA; 1.82 & I; 1.53 & $\mathrm{SA} ; 0.42$ & I*SA; 0.74 \\
\hline \multicolumn{7}{|c|}{ Fruit length $\left(\mathrm{cm}^{2}\right)$} \\
\hline non spraying SA & 38.20 & 36.27 & 32.64 & 37.61 & 35.67 & 32.63 \\
\hline spraying SA & 39.57 & 37.03 & 35.22 & 38.25 & 36.88 & 34.57 \\
\hline L.S.D. 0.05 & I; 1.25 & $\mathrm{SA} ; \quad 0.78$ & $\mathrm{I} * \mathrm{SA} ; 1.36$ & I; 0.85 & SA;1.01 & I*SA; 1.74 \\
\hline \multicolumn{7}{|l|}{ fruit width $(\mathrm{cm} 2)$} \\
\hline non spraying SA & 36.66 & 34.96 & 32.75 & 35.66 & 33.70 & 33.43 \\
\hline spraying SA & 37.83 & 35.63 & 34.82 & 35.42 & 35.91 & 33.70 \\
\hline L.S.D. 0.05 & I; 0.49 & SA;0.67 & I*SA; 1.17 & I; 0.53 & $\mathrm{SA} ; 0.53$ & I*SA;0.93 \\
\hline \multicolumn{7}{|c|}{ Reg weight \% } \\
\hline non spraying SA & 52.02 & 54.42 & 59.41 & 51.16 & 56.32 & 58.34 \\
\hline spraying SA & 51.85 & 52.00 & 57.51 & 52.37 & 54.12 & 56.48 \\
\hline L.S.D. 0.05 & I; 1.09 & $\mathrm{SA} ; 0.24$ & I*SA; 1.02 & I; 1.17 & $\mathrm{SA} ; 0.81$ & I*SA; 1.41 \\
\hline
\end{tabular}


Physico-chemic Juice al fruit attributes of lime fruits at harvest

Data in Table 4, cleared the effect of irrigation regime or spraying salicylic acid on juice weight $\%$. Decreasing the irrigation regime from 100 $\%$ to $80 \%$ and $60 \%$ induced a reduction in juice weight $\%$ from (48.07 to 46.79 and $41.5 \%$ ) in the first season and (48.23to 44.78 and $42.59 \%$ ) in the second season, respectively. Salicylic acid caused an improvement in the weight of the juice (46.21and 45.68) compared to untreated fruits (44.72and 44.73) in both seasons, respectively. There was a gradual increase in Total soluble solids $\%$ (TSS \%) with the decrease in irrigation regime from $100 \%$ to $80 \% 60 \%$ in both seasons. While, spraying salicylic acid was superior for raising TSS value. These results could be attributed to advance fruit maturity under drought condition. Titratable acidity \% (TA \%) was not significantly affected by all irrigation and spraying salicylic acid treatments, in $1^{\text {st }}$ and $2^{\text {nd }}$ seasons. Moreover, the irrigation regime and spraying salicylic acid failed to show any measurable effect on (TSS/ TA ratio). With regard to the effect of irrigation regime and spraying salicylic acid on vitamin $\mathrm{C}$ content (as mg of Ascorbic acid/100 ml juice) of lime fruit, it was found that, the percent of vitamin $\mathrm{C}$ content in lime fruit were increased by reducing irrigation regime and spraying salicylic acid. These finding was supported by Pérez-Pérez et al. (2009) on Sweet orange Lan late and Abo El-Enien (2012) on Navel orange, Zaghlou and Moursi (2017) on Navel Orange they found that, moderate water stress produced the highest TSS, acid ratio and as vitamin $\mathrm{C}$. The promoting effect of SA on plant pigments and the biosynthesis of carbohydrates surely reflected on advancing maturity and improving fruit quality (Shah, 2003). These results are in agreement with these obtained by Eshmawy (2010); Saied (2011) and Ahmed (2013) on Mango.

TABLE 4. Effect of irrigation regime, spraying salicylic acid on physico-chemic Juice al fruit attributes of lime fruits at harvest

\begin{tabular}{|c|c|c|c|c|c|c|}
\hline \multirow{2}{*}{$\begin{array}{l}\text { Irrigation } \\
\text { Spraying }\end{array}$} & $\begin{array}{c}100 \% \\
\text { ETc }\end{array}$ & $80 \%$ ETc & $60 \%$ ETc & $\begin{array}{c}100 \% \% \\
\text { ETc } \\
\end{array}$ & $\begin{array}{l}80 \% \\
\text { ETc } \\
\end{array}$ & $60 \%$ ETc \\
\hline & \multicolumn{4}{|c|}{2017} & \multicolumn{2}{|l|}{2018} \\
\hline \multicolumn{7}{|c|}{ Juice weight \% } \\
\hline non spraying SA & 47.98 & 45.58 & 40.59 & 48.84 & 43.68 & 41.66 \\
\hline spraying SA & 48.15 & 48.00 & 42.49 & 47.63 & 45.88 & 43.52 \\
\hline L.S.D. 0.05 & $\mathbf{I} ; 3.01$ & $\mathrm{SA} ; 0.59$ & $\mathrm{I} * \mathrm{SA} ; 1.03$ & I; 1.17 & SA;0.81 & $\mathrm{I} * \mathrm{SA} ; 1.41$ \\
\hline \multicolumn{7}{|c|}{ TSS \% } \\
\hline non spraying SA & 7.40 & 7.73 & 8.13 & 7.00 & 7.20 & 8.00 \\
\hline spraying SA & 7.50 & 7.77 & 8.43 & 7.30 & 7.40 & 8.20 \\
\hline L.S.D. 0.05 & I; 0.82 & SA; NS & $I * S A ; 0.26$ & I; $\quad 0.43$ & SA; NS & $I * S A ; 0.46$ \\
\hline \multicolumn{7}{|c|}{ TA } \\
\hline non spraying $\mathrm{SA}$ & 6.68 & 6.89 & 7.04 & 6.58 & 6.46 & 6.74 \\
\hline spraying SA & 6.78 & 6.91 & 7.17 & 6.69 & 6.68 & 7.04 \\
\hline L.S.D. 0.05 & I; NS & SA; NS & I*SA;NS & I; NS & SA; NS & $\mathbf{I} * \mathrm{SA} ; \mathrm{NS}$ \\
\hline \multicolumn{7}{|c|}{ TSS/TA ratio } \\
\hline non spraying SA & 1.11 & 1.12 & 1.15 & 1.06 & 1.11 & 1.19 \\
\hline spraying SA & 1.11 & 1.12 & 1.18 & 1.09 & 1.11 & 1.16 \\
\hline L.S.D. 0.05 & I; NS & SA; NS & I*SA; NS & I; NS & SA; NS & $\mathbf{I} * \mathbf{S A} ; \mathbf{N S}$ \\
\hline \multicolumn{7}{|c|}{ V.C content } \\
\hline non spraying $\mathbf{S A}$ & 49.87 & 57.79 & 59.40 & 50.16 & 53.68 & 59.40 \\
\hline spraying SA & 52.51 & 53.39 & 60.28 & 51.92 & 58.08 & 60.72 \\
\hline L.S.D. 0.05 & I; 2.71 & SA; NS & $I * S A ; 4.21$ & I; 0.61 & $\mathrm{SA} ; \mathbf{1 . 7 0}$ & I*SA; 2.94 \\
\hline
\end{tabular}

Env. Biodiv. Soil Security Vol. 4 (2020) 
Physico-chemical fruit attributes of lime fruits during marketing

Decay percentage

The results in Table 5, clearly showed that Decay Percentage were markedly increased with advanced of marketability period and reached its maximum values at the end of the marketing period. Also, decayed fruits could not be detected for 2 days being under room temperature and four days cold temperature in both seasons. Data indicated that the reduction irrigation water from $100 \%$ to $60 \%$ ETc decreased the decayed fruit percentage under both room temperature and cold temperature. Data proved that the spraying with SA, gave the best effect to prevent the fruits from decay compare to untreated with SA. The According to recorded data, it could be noticed that irrigated fruits with $60 \%$ with SA resulted in the least decay (\%) while irrigated with $100 \%$ gave the highest value of decay (\%). These results are in agreement with those reported by Abdel-Razik (2012) on mango, who reported that irrigation trees with $70 \%$ decreased decay $\%$ when compared with those irrigated with $100 \%$ ETc under cold storage, Hamdy (2017) on Valencia Orange who reported that irrigation trees with $60 \%$ decreased decay $\%$ when compared with those irrigated with 80 or $100 \%$ ETc under cold storage. Exogenous application of SA provided efficient control of decay caused by post harvest pathogens. Khademi and Ershadi (2013) and inducing systemic resistances against post harvest pathogen which extend storability of fruits with higher antioxidant activity that activates natural defense mechanism (Muzammil et al. 2014).

TABLE 5. Effect of irrigation regime, spraying salicylic acid on decay of lime fruits during marketing

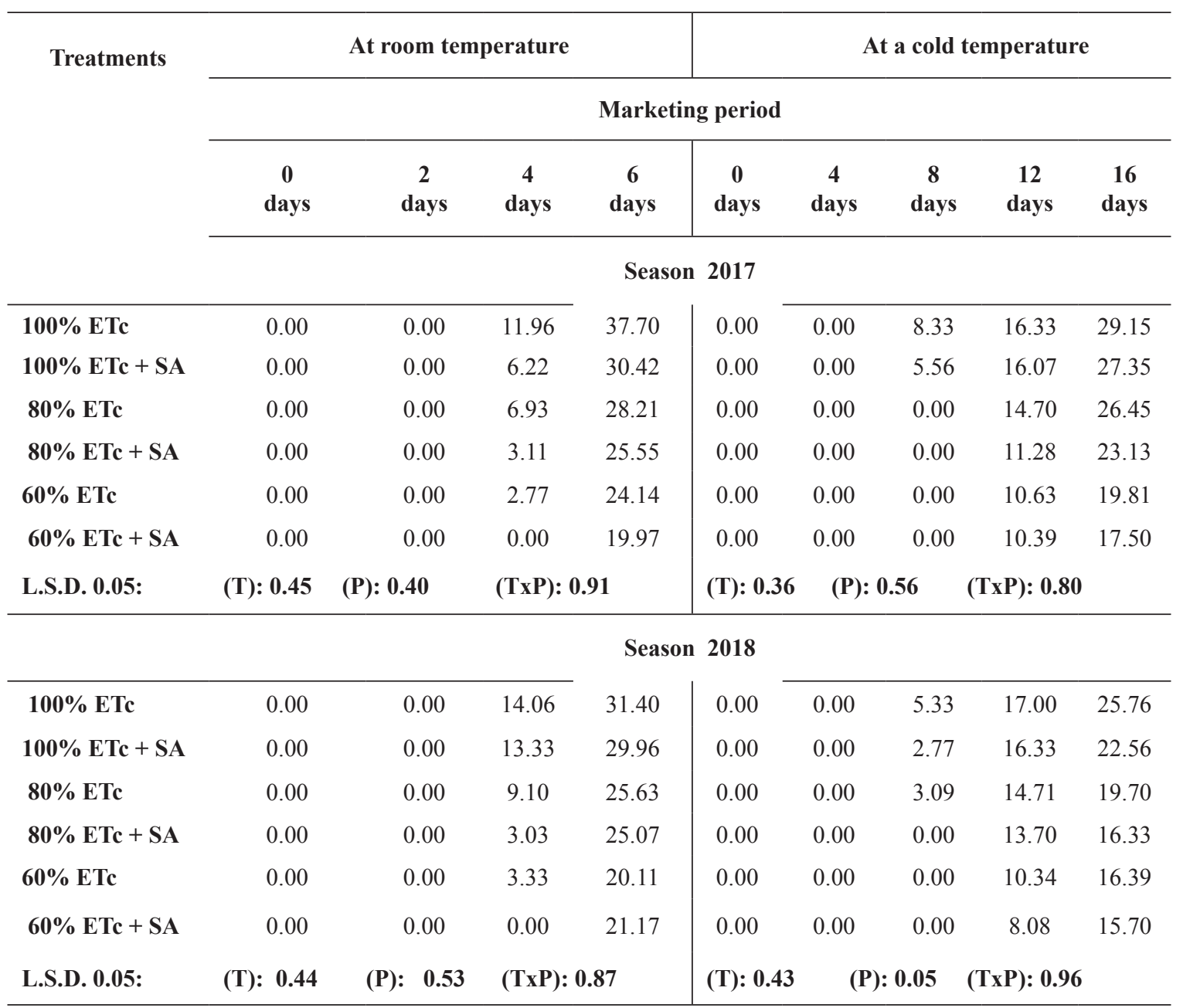




\section{Fruit weight loss}

Data in Table 6, clear that fruit weight loss were markedly increased with advanced of marketability period, which may be due to respiration and transpiration of water through peel tissue and perishable fruit is a serious concern in its marketability because loss of moisture decreases visual quality; salable weight and may result in physiological dysfunctions. Furthermore, all treatments were significant in reducing weight loss compare with control. A decrease in fruit weight loss percentages was noticed when the trees received $60 \%$ of water compared with $100 \%$, while the loss in weight percentages were increased in general by increasing number of days being under room temperature and cold temperature. The present results are in agreement with those obtained by of Abdel-Razik (2012) who studied that fruits of mango trees treated with $70 \%$ of ETc gained lower weight loss as compared with that of other treatments, And Hamdy et al. (2017) on Washington navel orange who indicated that trees treated with $60 \%$ of ETc gained lower weight loss as compared with that of other treatments. On the other hand, spraying SA reduced weight loss. As for data concerning SA are in line with those of Sartaj et al. (2013) who reported that higher concentrations of salicylic acid that role as an electron donor produces free radical which decrease normal respiration and transpiration.

TABLE 6. Effect of irrigation regime, spraying salicylic acid on weight loss $\%$ of lime fruits during marketing

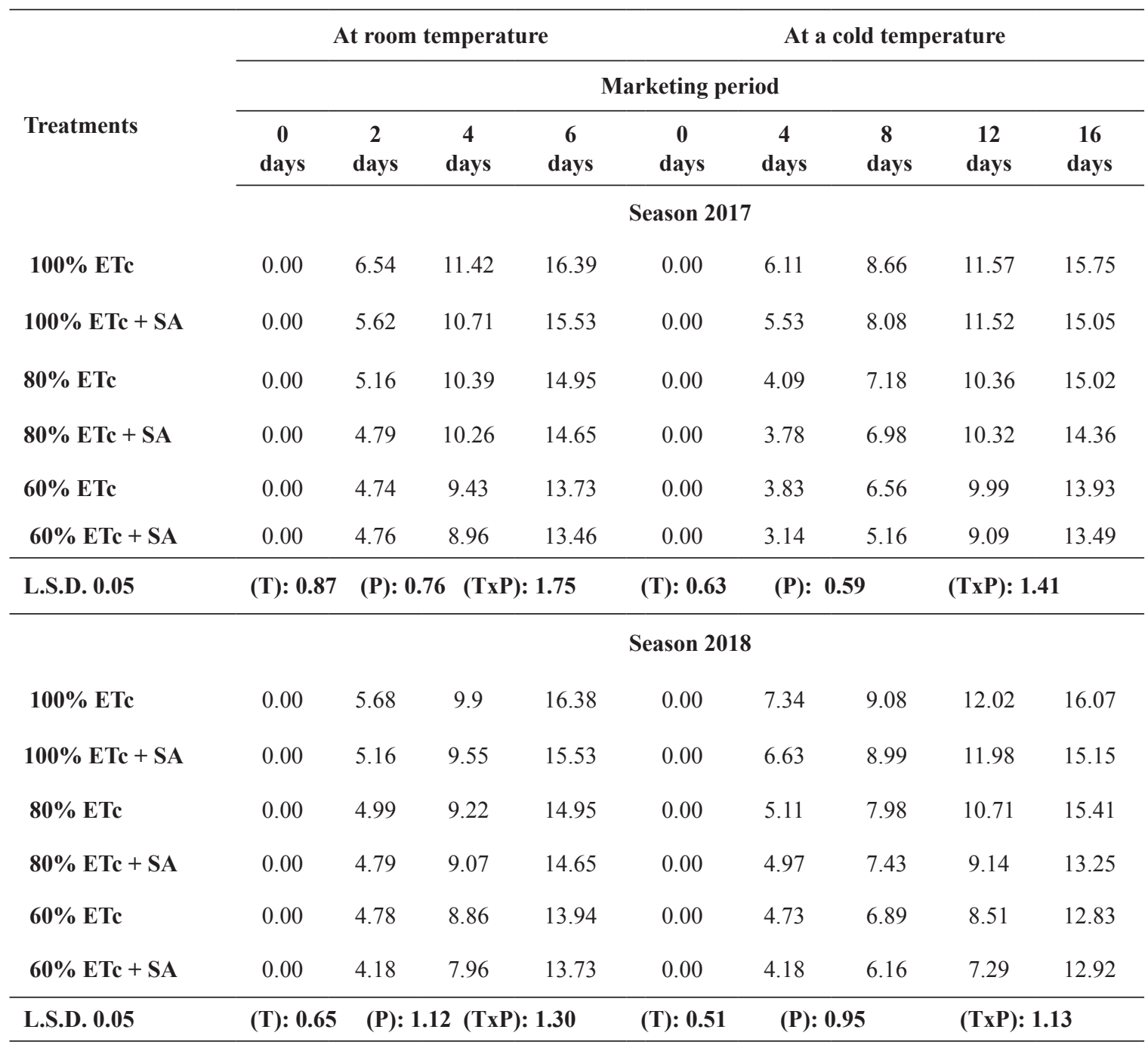


Juice weight

Presented data in Table 7, receded that, fruit Juice content \% was gradually and proportionally decreased with decreasing either the irrigation water $\%$ of ETc from $100 \%$ to $60 \%$ or with increasing marketability period under Room temperature and cold temperature in lime in both seasons. At the end of marketing period the lowest value of juice content $\%$ were found in the ETc $60 \%$ fruits (36.59 and $36.60 \%$ ) in room temperature and (36.66 and $36.60 \%$ ) in cold marketing during 2017 and 2018 seasons, respectively. On the other hand, it was clear that SA has reduced the decrease in juice weight \% It could be noticed that fruit treated with SA during growth season resulted in the highest level of juice weight $\%$, compared with untreated.

Total soluble solids percentage

Data in Table 8, cleared that, Total soluble solids percentage significantly increased and gradually from the beginning of marketability either in room temperature or cold temperature till the six days or Sixteen days, respectively. Thus, the maximum values of TSS\% were recorded at the end of marketing period in both seasons. Total soluble solids percentage is a function of total dissolved solids and moisture content of fruit and the increase in TSS\% may be due to loss of fruit moisture content during marketing period. Moreover, results indicated that TSS\% was increased by decreasing of irrigation water given to the trees whereas maximum increase was recorded at $60 \%$ of ETc. These results are in harmony with those found by Abdel-Razik (2012) on mango trees and Hamdy (2017) on Valencia Orange. In addition, there was no significant difference between fruits treated with salicylic acid and untreated fruits under the same level of irrigation. These results agree with those obtained by Ranjbaran et al. (2011) on grapes reported that SA treatment had no effect on TSS. Contrarily, (Khademi and Ershadi, 2013).

TABLE 7. Effect of irrigation regime, spraying salicylic acid on juice weight \% of lime fruits during marketing

\begin{tabular}{|c|c|c|c|c|c|c|c|c|c|}
\hline \multirow[b]{3}{*}{ Treatments } & \multicolumn{4}{|c|}{ At room temperature } & \multicolumn{5}{|c|}{ At a cold temperature } \\
\hline & \multicolumn{9}{|c|}{ Marketing period } \\
\hline & $\begin{array}{c}0 \\
\text { days }\end{array}$ & $\begin{array}{c}2 \\
\text { days }\end{array}$ & $\begin{array}{c}4 \\
\text { days }\end{array}$ & $\begin{array}{c}6 \\
\text { days }\end{array}$ & $\begin{array}{c}0 \\
\text { days }\end{array}$ & $\begin{array}{c}4 \\
\text { days }\end{array}$ & $\begin{array}{c}8 \\
\text { days }\end{array}$ & $\begin{array}{c}12 \\
\text { days }\end{array}$ & $\begin{array}{c}16 \\
\text { days }\end{array}$ \\
\hline & \multicolumn{9}{|c|}{ Season 2017} \\
\hline $100 \%$ ETc & 47.98 & 43.37 & 40.65 & 37.29 & 47.98 & 46.08 & 44.16 & 42.53 & 39.58 \\
\hline $100 \% \mathrm{ETc}+\mathrm{SA}$ & 48.15 & 44.86 & 40.63 & 37.31 & 48.15 & 47.31 & 45.07 & 44.62 & 40.35 \\
\hline $80 \%$ ETc & 45.58 & 41.89 & 39.46 & 37.21 & 45.58 & 43.56 & 41.94 & 40.74 & 39.44 \\
\hline $80 \% \mathrm{ETc}+\mathrm{SA}$ & 48.00 & 44.30 & 41.11 & 37.51 & 48.00 & 44.12 & 43.91 & 40.91 & 40.91 \\
\hline $60 \%$ ETc & 40.59 & 38.86 & 37.68 & 36.59 & 40.59 & 40.59 & 43.26 & 41.79 & 36.66 \\
\hline $60 \% \mathrm{ETc}+\mathrm{SA}$ & 42.49 & 39.84 & 37.04 & 37.04 & 42.49 & 40.48 & 42.66 & 39.44 & 38.00 \\
\hline \multirow[t]{2}{*}{ L.S.D. 0.05} & \multicolumn{4}{|c|}{$(T): 0.92$ (P): 0.59 (TxP): .85 } & \multicolumn{5}{|c|}{$\begin{array}{lll}\text { (T) 0.74: } & \text { (P): } 0.43 & \text { (TxP): } 1.65\end{array}$} \\
\hline & \multicolumn{9}{|c|}{ Season 2018} \\
\hline $100 \%$ ETc & 48.84 & 44.81 & 43.86 & 40.18 & 48.84 & 44.81 & 44.18 & 40.18 & 38.38 \\
\hline $100 \% \mathrm{ETc}+\mathrm{SA}$ & 47.63 & 44.92 & 43.25 & 44.45 & 47.63 & 45.92 & 44.63 & 43.45 & 42.38 \\
\hline $80 \%$ ETc & 43.68 & 43.68 & 42.15 & 40.77 & 43.68 & 43.68 & 41.88 & 40.44 & 40.40 \\
\hline $80 \% \mathrm{ETc}+\mathrm{SA}$ & 45.88 & 43.24 & 42.38 & 40.83 & 45.88 & 43.24 & 42.71 & 40.83 & 41.94 \\
\hline $60 \%$ ETc & 41.66 & 40.73 & 37.52 & 36.60 & 41.66 & 43.73 & 41.46 & 40.68 & 36.60 \\
\hline $60 \% \mathrm{ETc}+\mathrm{SA}$ & 43.52 & 42.12 & 38.69 & 37.55 & 43.52 & 42.12 & 41.68 & 41.51 & 39.55 \\
\hline L.S.D. 0.05 & \multicolumn{4}{|c|}{ (T): 3.41 (P): 3.37 (TxP } & \multicolumn{5}{|c|}{ (T): 0.81 (P): 0.96 (TxP): 1.82} \\
\hline
\end{tabular}


TABLE 8. Effect of irrigation regime, spraying salicylic acid on total soluble solids percentage (TSS \%) of lime fruits during marketing

\begin{tabular}{|c|c|c|c|c|c|c|c|c|c|}
\hline \multirow{4}{*}{ Treatments } & At room & temperatur & & & & At a & d temp & ature & \\
\hline & \multicolumn{9}{|c|}{ Marketing period } \\
\hline & $\begin{array}{c}0 \\
\text { days }\end{array}$ & $\begin{array}{c}2 \\
\text { days }\end{array}$ & $\begin{array}{c}4 \\
\text { days }\end{array}$ & $\begin{array}{c}6 \\
\text { days }\end{array}$ & $\begin{array}{c}0 \\
\text { days }\end{array}$ & $\begin{array}{c}4 \\
\text { days }\end{array}$ & $\begin{array}{c}8 \\
\text { days }\end{array}$ & $\begin{array}{c}12 \\
\text { days }\end{array}$ & $\begin{array}{c}16 \\
\text { days }\end{array}$ \\
\hline & \multicolumn{9}{|c|}{ Season 2017} \\
\hline $100 \%$ ETc & 7.40 & 7.77 & 7.80 & 8.00 & 7.40 & 7.50 & 7.37 & 8.00 & 8.07 \\
\hline $100 \% \mathrm{ETc}+\mathrm{SA}$ & 7.50 & 7.80 & 7.90 & 8.17 & 7.50 & 7.53 & 7.83 & 7.93 & 8.13 \\
\hline $80 \%$ ETc & 7.73 & 7.57 & 7.73 & 8.07 & 7.73 & 7.23 & 8.00 & 8.07 & 8.13 \\
\hline $80 \% \mathbf{E T c}+\mathrm{SA}$ & 7.77 & 7.67 & 7.73 & 8.33 & 7.77 & 7.73 & 7.80 & 7.87 & 8.13 \\
\hline $60 \%$ ETc & 8.13 & 8.27 & 8.43 & 9.33 & 8.13 & 8.00 & 8.07 & 8.47 & 9.00 \\
\hline $60 \% \mathrm{ETc}+\mathrm{SA}$ & 8.43 & 8.60 & 8.73 & 9.00 & 8.43 & 8.60 & 8.73 & 8.93 & 9.03 \\
\hline \multirow[t]{2}{*}{ L.S.D. 0.05} & \multicolumn{4}{|c|}{$(T): 0.17$ (P): $0.21 \quad(T x P): 0.34$} & \multicolumn{3}{|c|}{$(T): 0.18 \quad(P): 0.35$} & \multicolumn{2}{|c|}{ (TxP): 0.41} \\
\hline & \multicolumn{9}{|c|}{ Season 2018} \\
\hline $100 \%$ ETc & 7.00 & 7.50 & 8.00 & 8.40 & 7.00 & 7.20 & 7.80 & 8.00 & 8.40 \\
\hline $100 \%$ ETc + SA & 7.30 & 7.50 & 8.00 & 8.20 & 7.30 & 7.40 & 7.60 & 8.20 & 8.40 \\
\hline $80 \%$ ETc & 7.20 & 7.50 & 8.00 & 8.50 & 7.20 & 7.80 & 8.00 & 8.20 & 8.60 \\
\hline $\mathbf{8 0} \% \mathbf{E T c}+\mathrm{SA}$ & 7.40 & 7.50 & 7.80 & 8.33 & 7.40 & 7.80 & 8.00 & 8.20 & 8.40 \\
\hline $60 \%$ ETc & 8.00 & 8.60 & 9.00 & 9.13 & 8.00 & 8.13 & 8.30 & 8.80 & 9.33 \\
\hline $60 \% \mathrm{ETc}+\mathrm{SA}$ & 8.20 & 8.40 & 8.60 & 9.00 & 8.20 & 8.30 & 8.40 & 8.60 & 9.00 \\
\hline L.S.D. 0.05 & $(T): 0.39$ & $(\mathrm{P}): 0.31$ & (TxP): 0.79 & & & & 0.28 & (TxP & \\
\hline
\end{tabular}

\section{Titratable acidity}

Data presented in Table 9, indicated that gradual decrease for titratable acidity was found in all treatments. Hence the minimum TA\% was recorded at the end of marketability period in room temperature or cold during the two studied seasons. The highest value of acidity was found at $60 \%$ of ETc, while the lowest at $100 \%$ of ETc. while, fruits treated with SA retained higher content of TA during the entire storage period compare to untreated fruits. These results are in line with those reported by Chanikan et al. (2015) who illustrated that the slight decline in TA was probably due to the slow rate of respiration and metabolic processes converting citric acid into sugars as a function of applied SA.

\section{TSS / TA ratio}

Presented data in Table 10, indicated that A gradual increase for TSS / TA was found in all treatments. Hence the minimum TSS / TA were recorded at the end of marketability period in room temperature or cold during the two studied seasons. All treatments were not significant TSS / TA during marketing at room temperature. While it was significant in its impact during cold marketing in both seasons of study The results are in agreement with those obtained by Abdel-Razik (2012) on mango trees and Hamdy (2017) on
Valencia Orange. On the other hand, our results agree with those of Sartaj et al., (2013) who found that $2 \mathrm{mM}$ of salicylic acid was effective in retaining keeping quality of apricot up to 12 days at ambient storage.

\section{Ascorbic acid}

Data in Table 11, indicated that, during marketability period the ascorbic acid content of fruits gradually decreased with prolonging the marketability period at room temperature or cold. Moreover, fruit V.C content was affected by irrigation treatments. Significant differences were noticed between fruits in relation to water regime as fruits of trees received $60 \%$ of ETc possessed the highest vitamin $\mathrm{C}$ values under room temperature or cold followed descendingly by those receiving $80 \%$ and $100 \%$ treated fruit with SA reduced the loss of ascorbic acid in fruits compared with un treated. The conserving of ascorbic acid \% in fruits which were treated with SA due to the reducing of respiration process and water loss thus decreasing of oxidation of ascorbic acid content compared with the reducing rate of ascorbic acid in control where increase respiration process and there for increasing of oxidation. The results of this study were in line with Ali et al. (2009), Ali et al. (2013). AbdelRazik et al. (2012) and Hamdy et al. (2017). 
TABLE 9. Effect of irrigation regime, spraying salicylic acid on titratable acidity \% (TA) of lime fruits during marketing

\begin{tabular}{|c|c|c|c|c|c|c|c|c|c|}
\hline \multirow{4}{*}{ Treatments } & At room t & ature & & & & At a c & tempe & ature & \\
\hline & \multicolumn{9}{|c|}{ Marketing period } \\
\hline & $\begin{array}{c}0 \\
\text { days }\end{array}$ & $\begin{array}{c}2 \\
\text { days }\end{array}$ & $\begin{array}{c}4 \\
\text { days }\end{array}$ & $\begin{array}{c}6 \\
\text { days }\end{array}$ & $\begin{array}{c}0 \\
\text { days }\end{array}$ & $\begin{array}{c}4 \\
\text { days }\end{array}$ & $\begin{array}{c}8 \\
\text { days }\end{array}$ & $\begin{array}{c}12 \\
\text { days }\end{array}$ & $\begin{array}{c}16 \\
\text { days }\end{array}$ \\
\hline & \multicolumn{9}{|c|}{ Season 2017} \\
\hline $100 \%$ ETc & 6.68 & 6.10 & 5.89 & 5.78 & 6.68 & 6.61 & 6.46 & 6.11 & 5.85 \\
\hline $100 \% \mathrm{ETc}+\mathrm{SA}$ & 6.78 & 6.14 & 5.89 & 5.63 & 6.78 & 6.58 & 6.41 & 5.98 & 5.89 \\
\hline $80 \%$ ETc & 6.89 & 5.89 & 5.76 & 5.63 & 6.89 & 6.31 & 6.23 & 6.21 & 5.96 \\
\hline $80 \%$ ETc + SA & 6.91 & 6.14 & 5.89 & 5.75 & 6.91 & 6.10 & 5.96 & 5.59 & 5.75 \\
\hline $60 \%$ ETc & 7.04 & 6.66 & 6.55 & 6.12 & 7.04 & 6.60 & 6.39 & 5.88 & 5.71 \\
\hline $60 \% \mathrm{ETc}+\mathrm{SA}$ & 7.17 & 6.66 & 6.58 & 6.14 & 7.17 & 6.74 & 6.22 & 6.12 & 6.13 \\
\hline \multirow[t]{2}{*}{ L.S.D. 0.05} & \multicolumn{4}{|c|}{$(\mathrm{T}): 0.45$ (P): 0.39 (TxP): 0.90} & \multicolumn{5}{|c|}{$(T): 0.22 \quad(P): 0.13 \quad(T \times P): 0.51$} \\
\hline & \multicolumn{9}{|c|}{ Season 2018} \\
\hline $100 \%$ ETc & 6.58 & 6.45 & 6.16 & 5.68 & 6.58 & 6.53 & 6.09 & 6.42 & 5.68 \\
\hline $100 \% \mathrm{ETc}+\mathrm{SA}$ & 6.69 & 6.62 & 6.49 & 5.89 & 6.69 & 6.17 & 6.09 & 6.06 & 5.89 \\
\hline $80 \%$ ETc & 6.46 & 6.14 & 5.85 & 5.89 & 6.46 & 6.14 & 6.09 & 6.02 & 5.69 \\
\hline $80 \%$ ETc + SA & 6.68 & 6.63 & 6.11 & 6.02 & 6.68 & 6.40 & 6.04 & 5.89 & 5.55 \\
\hline $60 \%$ ETc & 6.74 & 6.64 & 6.55 & 5.76 & 6.74 & 6.96 & 6.68 & 6.36 & 5.76 \\
\hline $60 \% \mathrm{ETc}+\mathrm{SA}$ & 7.04 & 6.62 & 6.31 & 6.14 & 7.04 & 6.91 & 6.87 & 6.31 & 6.14 \\
\hline L.S.D. 0.05 & (T): 0.18 & .16 & xP): 0. & & & 0.23( & 0.09 & (TxP): 0 & \\
\hline
\end{tabular}

TABLE 10. Effect of irrigation regime, spraying salicylic acid on TSS/TA ratio of lime fruits during marketing

\begin{tabular}{|c|c|c|c|c|c|c|c|c|c|}
\hline \multirow[b]{3}{*}{ Treatments } & \multicolumn{4}{|c|}{ At room temperature } & \multicolumn{5}{|c|}{ At a cold temperature } \\
\hline & \multicolumn{9}{|c|}{ Marketing period } \\
\hline & $\begin{array}{c}0 \\
\text { days }\end{array}$ & $\begin{array}{c}2 \\
\text { days }\end{array}$ & $\begin{array}{c}4 \\
\text { days }\end{array}$ & $\begin{array}{c}6 \\
\text { days }\end{array}$ & $\begin{array}{c}0 \\
\text { days }\end{array}$ & $\begin{array}{c}4 \\
\text { days }\end{array}$ & $\begin{array}{c}8 \\
\text { days }\end{array}$ & $\begin{array}{c}12 \\
\text { days }\end{array}$ & $\begin{array}{c}16 \\
\text { days }\end{array}$ \\
\hline & \multicolumn{9}{|c|}{ Season 2017} \\
\hline $100 \%$ ETc & 1.11 & 1.27 & 1.32 & \multirow{6}{*}{$\begin{array}{l}1.38 \\
1.45 \\
1.43 \\
1.45 \\
1.52 \\
1.47\end{array}$} & 1.11 & 1.13 & 1.14 & 1.31 & \multirow{2}{*}{$\begin{array}{l}1.38 \\
1.38\end{array}$} \\
\hline $100 \% \mathrm{ETc}+\mathrm{SA}$ & 1.11 & 1.27 & 1.34 & & 1.11 & 1.14 & 1.22 & 1.33 & \\
\hline $80 \%$ ETc & 1.12 & 1.29 & 1.34 & & 1.12 & 1.15 & 1.28 & 1.30 & \multirow{4}{*}{$\begin{array}{l}1.36 \\
1.41 \\
1.58 \\
1.47\end{array}$} \\
\hline $80 \% \mathbf{E T c}+\mathrm{SA}$ & 1.12 & 1.25 & 1.31 & & 1.12 & 1.27 & 1.31 & 1.41 & \\
\hline $60 \%$ ETc & 1.15 & 1.24 & 1.29 & & 1.15 & 1.21 & 1.31 & 1.44 & \\
\hline $60 \% \mathrm{ETc}+\mathrm{SA}$ & 1.18 & 1.29 & 1.33 & & 1.18 & 1.28 & 1.40 & 1.46 & \\
\hline \multirow[t]{2}{*}{ L.S.D. 0.05} & (T):NS & (P): NS & $(\mathrm{TxP})$ & & & .23 & (P): 0.13 & $(T x$ & 0.51 \\
\hline & \multicolumn{9}{|c|}{ Season 2018} \\
\hline $100 \%$ ETc & 1.06 & 1.16 & 1.30 & \multirow{6}{*}{$\begin{array}{l}1.48 \\
1.39 \\
1.44 \\
1.38 \\
1.59 \\
1.47\end{array}$} & 1.06 & 1.10 & 1.28 & 1.25 & \multirow[b]{2}{*}{$\begin{array}{l}1.48 \\
1.43\end{array}$} \\
\hline $100 \% \mathrm{ETc}+\mathrm{SA}$ & 1.09 & 1.13 & 1.23 & & 1.09 & 1.20 & 1.25 & 1.35 & \\
\hline $80 \%$ ETc & 1.11 & 1.22 & 1.37 & & 1.11 & 1.27 & 1.31 & 1.35 & \multirow{4}{*}{$\begin{array}{l}1.01 \\
1.51 \\
1.62 \\
1.47\end{array}$} \\
\hline $80 \%$ ETc + SA & 1.11 & 1.13 & 1.28 & & 1.11 & 1.22 & 1.32 & 1.39 & \\
\hline $60 \%$ ETc & 1.19 & 1.30 & 1.37 & & 1.19 & 1.17 & 1.24 & 1.38 & \\
\hline $60 \% \mathrm{ETc}+\mathrm{SA}$ & 1.16 & 1.27 & 1.36 & & 1.16 & 1.20 & 1.22 & 1.36 & \\
\hline L.S.D. 0.05 & (T): NS & (P): NS & $(\mathrm{TxP})$ & & ( $\mathrm{T}$ & 0.05 & (P): 0.02 & $(\mathbf{T} \mathbf{x}$ & 0.12 \\
\hline
\end{tabular}


TABLE 11. Effect of irrigation regime, spraying salicylic acid on vitamin C content of lime fruits during marketing

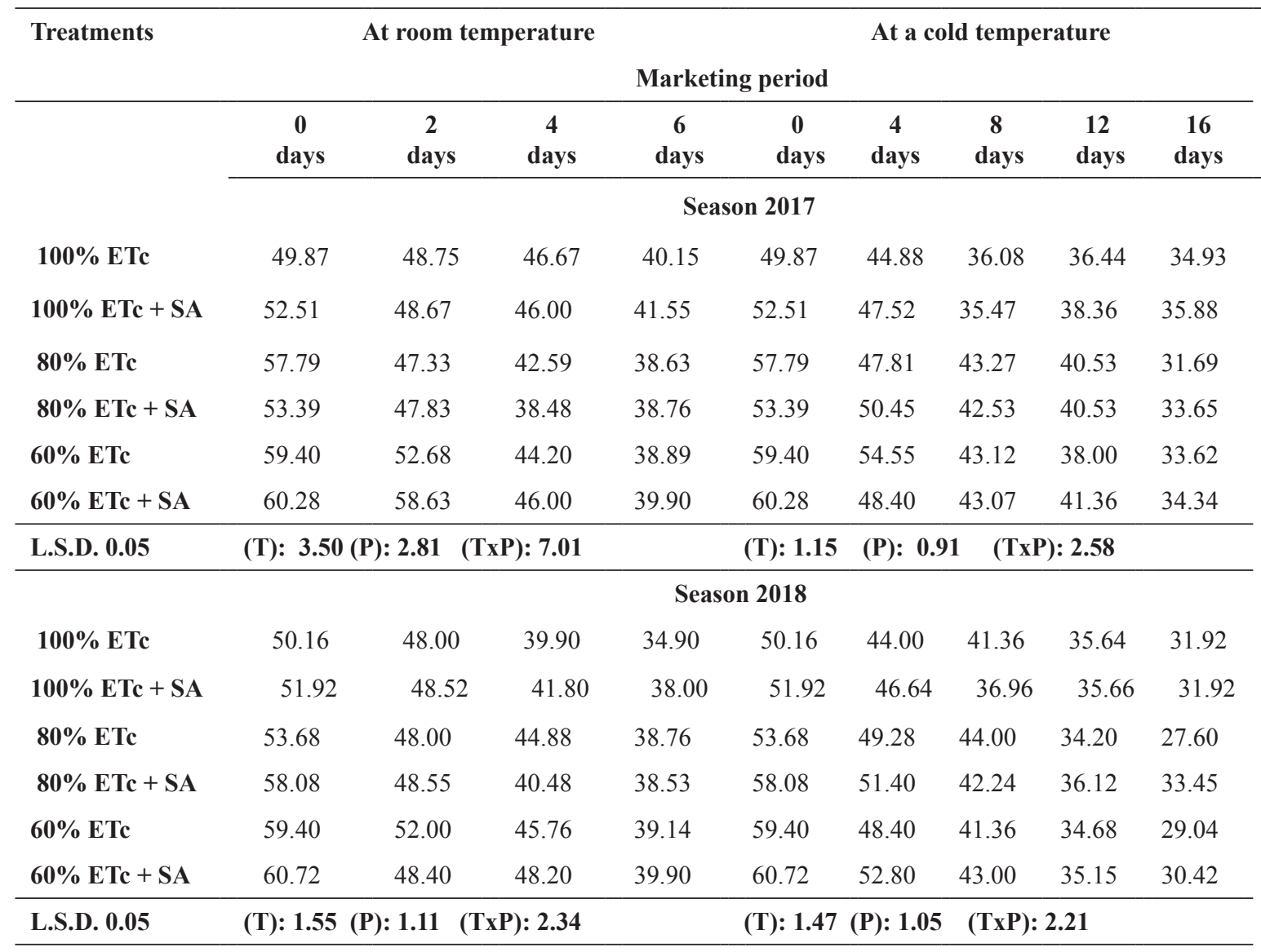

\section{Conclusion}

This current investigation recommended that, under Asyut region, Irrigation lime trees with $100 \%$ ETc to have the highest yield and its component, in addition spraying salicylic acid to obtain the best irrigation water productivity, economic water productivity and reduced weight loss of marketability yield. Hence, could be used successfully for other crops as well as become important for Egyptian agriculture, especially when economic and environmental points of view are considered.

\section{Ethics approval and consent to participate}

This article does not contain any studies with human participants or animals performed by any of the authors.

\section{Consent for publication}

All authors declare their consent for publication.

\section{Funding}

This research received no external funding.

Env. Biodiv. Soil Security Vol. 4 (2020)
Conflicts of Interest: The author declares no conflict of interest.

Acknowledgments: The authors gratefully acknowledge to Assiut Agriculture Research Station for providing us the land and the tools to make this work. Also, authors gratefully thank the staff members of water requirements and field irrigation, soil\& water and environment Res. Inst and Horticultural Res. Inst Agriculture research center, Egypt for their excellent technical assistance.

\section{References}

Abo El-Enien, M. S. (2012) Improvement of Washington Navel orange fruit quality using water regimes and GA3, potassium and calcium foliar applications. Ph.D. Thesis, Fac. Agric. Kafr ElSheikh Univ., Egypt.

Ahmed, F.F., Mansour A.E. M. and Merwad, M.A. (2015a) Physiological studies on the effect of spraying salicylic acid on fruiting of 'Sukkary' mango trees. International Journal of Chem Tech Research 8: 2142-2149.

Ahmed, E.F.S. (2011) Response of Sakkoti date palms to foliar application of salicylic acid. Minia J. of 
Agric. Res. \& Develop. 31 (2): 305-316.

Ahmed, F.F., Kamel, M. Kh. and Ibrahim, H.I.M. (2014) The synergistic effect of using plant extracts and salicylic acid on yield and fruit quality of Keitte mango trees. Stem Cell, 5 (2): 30-39.

Al- Naeem, A.A. (2014) Estimation of evapotranspiration of citrus tree from climate data for groundwater management in Saudi Arabia. Research J. of Envir. Sci. 8 (8): 435-443.

Ali, B.A., Ziada, A. and Blunden, G. (2009) Biology effects of Arabic gum: A review of some recent research. Food and Chemical Toxicology, 47: 1-8.

Ali, E., Mokhtar, H., Mohammad, H.D. and Sadegh, T. (2013) Studying effects of edible coatings of Arabic gum and olive oil on the storage life and maintain quality of postharvest Sweet Lemon (Citrus Lemontta). International Journal of Agriculture and Crop Sciences. IJACS/2014/7-4/207-213.

Ali, M.H., Hoque, M.R., Hassan, A.A. and khair, A. (2007) Effects of deficit irrigation on yield, water productivity and economic returns of wheat. Agricultural water management, 92 (3): 151-161.

Arfan, M., Athar, H.R. and Ashraf, M. (2007) Does Exogenous Application of Salicylic Acid through the Rooting Medium Modulate Growth and Photosynthetic Capacity in Two Differently Adapted Spring Wheat Cultivars under Salt Stress. Journal of Plant Physiology, 164 (6): 685-694.

Asghari M. and Aghdam, M. S. (2010) Impact of salicylic acid on post-harvest physiology of horticultural crops. Trends Food Sci. Technol. 21 502-509.

Ashraf, M.Y., Yaqub, M., Akhter, J., Khan, M.A., Khan, A. and Ebert, G. (2013) Improvement in yield, quality and reduction in fruit drop in kinnow (Citrus reticulata Blanco) by exogenous application of plant growth regulators, potassium and zinc. Pakistan Journal of Botany. 45: 433-440.

Behboudian, M.H., Lawes, G.S. and Griffiths, K.M. (1994) The influence of water deficit on water relation, photosynthesis and fruit growth in Asian pear (Pyrus serotina Rehd.). Scientia Horticulture, 60: $84-99$.

Bezrukova, M.V., Sakhabutdinova, R., Fatkhutdinova, R.A., Kyldiar, I. and Shakirova, F. (2001) The role of hormonal changes in protective action of salicylic acid on growth of wheat seedlings under water deficit. Agrochemya (Russ.), 2: 51-54.

Chanikan, J., Faiyueb, B., Rotarayanonta, S.,
Uthaibutra, J. and Boonyakiatc, D. (2015) Cold storage in salicylic acid increases enzymatic and non-enzymatic anti and oxidants of Nam Dok Mai No. 4 mango fruit. Science Asia, 41: 12-21.

Darwesh, R. Kh. (2018) Water productivity for Egyptian clover as affected by different irrigation regimes and cultivation methods in The North Middle Nile Delta Region. Env. Biodiv. Soil Security, 2,193 - 203.

El-Abd, A.A., Moursiand, E.A. and Gaber, M. A. (2012) Effect of irrigation water regime on navel orange yield, fruit quality and some water relation in the north middle Nile Delta region. J. plant production, Mansoura Univ., 3:1049-1061.

El-Quosy, D. (1998) The challenge for water in the twenty first century. The Egyptian experience. Arab. Water 98. Ministry of Water Resources and Irrigation (MWR) April 26-28, 1998, Cairo, Egypt.

Ennab, H. A., Mervat A. El-Shemy and Shame M. Alam-Eldein (2020) Salicylic Acid and Putrescine to Reduce Post-Harvest Storage Problems and Maintain Quality of Murcott. Mandarin Fruit Agronomy, 10, 115

Eshmawy, E.M. Sh. (2010) Effect of some antioxidants and different pollination methods on fruiting of Sewy date palms. M. Sc. Thesis, Fac. of Agric. Minia Univ. Egypt.

Glowacz, M. and Ree, D. (2015) Using jasmonates and salicylates to reduce losses within the fruit supply chain. Eur. Food Res. Technol. 242, 143-156.

Haidera, S., Tul-Ain, S. Ahmad, Ahmad, Khan, S., Anjum, M.A., Nasir, M. and Naz, S. (2020) Effects of salicylic acid on postharvest fruit quality of "Kinnow" mandarin under cold storage. Scientia Horticulturae, 259

Hamdy. A. E., Khalifa, S. M. and Abobatta, W. F. R. (2017) Effect of Water Deficit on Fruit Quality and Storability of Valencia Orange Fruits Under Cold Storage Conditions. $1^{\text {st }}$ Int. Conf. Fac. Agric. Alex. Univ. 22-23 Feb., 2017, Alex. J. Agric. Sci. 62 (6): $39-46$

Horvath, E., Szalai, G. and Janda, T. (2007) Induction of Abiotic Stress Tolerance by Salicylic Acid Signaling. Journal of Plant Growth Regulation, 26 (3): 290- 300 .

Abdelfattah, I. M., Attia, E. and El-Banna, G. M. (2020) Irrigation scheduling and its impacts on freesia-water productivity, vegetative and 
flowering parameters under greenhouse cultivation. Environment, Biodiversity and Soil Security, 4, 5971.

Ibrahim, A.M. and Abd El-Samad, G.A. (2009) Effect of different irrigation regimes and partial substitution of $\mathrm{N}$-mineral by organic manures on water use, growth and productivity of pomegranate trees. Europ. J. Sci. Res., 38 (2): 199-218.

Jamshidi, S., Zand-Pars, S., Kamgar-Haghighi, A. A., Shahsavar, A. R. and Niyogi, D. (2020) Evapotranspiration, crop coefficients, and physiological responses of citrus trees in semiarid climatic conditions. Agricultural Water Management, 227: 1-12

Kallsen, C. E., Sanden, B. and Arpaia, M. L. (2011) Early navel orange fruit yield, quality, and maturity in response to late-season water stress. HortScience, 46(8), 1163-1169.

Khademi, Z. and Ershadi, A. (2013) Postharvest Application of Salicylic Acid Improves Storability of Peach (Prunus persicacv. Elberta) Fruits. Intern. J. of Agric. and Crop Sci., 5 (6): 651-655.

Koo, Y. M., Heo, A. Y. and Choi, H. W. (2020) Salicylic acid as a safe plant protector and growth regulator. Plant Pathol. J. 36, 1-10.

Lee, H.L., Leon, J. and Raskin, I. (1995) Biosynthesis and metabolism of salicylic acid. Proceedings of the National Academy of Sciences USA. 92:40764079.

Li, S.H., Huguet, J.G., Schoch, P.G. and Orlando, P. (1989) Response of peach tree growth and cropping to soil water deficit at various phonological stages of fruit development. J. Hort. Sci. 64: 541-552.

Lokesh G, Madhumathi, C., Rama K.M., Tanuja P. B. and Lalitha K. (2020) Influence of Preharvest Application of Salicylic Acid and Potassium Silicate on Postharvest Quality of Mango Fruits (Mangifera indica L.) cv. Alphonso. Acta Scientific Agriculture (4). 4

Khattab, M. M., Shaban, A. E., El-Shrief, A. H. and El-Deen Mohamed, A. S. (2011) Growth and productivity of pomegranate trees under different irrigation levels. I: Vegetative growth and fruiting. J. Hortic. Sci. Ornam. Plants, 3 (2), 194-198.

Aiad, M. A. E. F. (2019) Productivity of Heavy Clay Soils as Affected by Some Soil Amendments Combined with Irrigation Regime. Environment, Biodiversity and Soil Security, 3, 147-162.

Env. Biodiv. Soil Security Vol. 4 (2020)
Amer, M. M., Aiad, M. A. E. F., Rashed, S. H. and El-Ramady, H. (2019) Irrigation and Fertilization Management of Successive Cultivated Sugar Beet and Cotton under Salt-Affected Soil Conditions. Environment, Biodiversity and Soil Security, 3, 227-239.

Amer, M. M., Abou El Soud, H. M., Rashad, S. H. and Gaiza, S. A. (2020) Contribution of management of irrigation water and organic application in improving some soil properties and its water productivity of sugar beet and cotton. Environment, Biodiversity and Soil Security, 4, 5-10.

Metwally, A., Finkemeier, I., Georgi, M. and Dietz, K. J. (2003) Salicylic Acid Alleviates the Cadmium Toxicity in barley Seedlings. Plant Physiology, 132 (1): 272-281.

Mikhael, G.B. and Mady, A.A. (2007) Effect of some drip irrigation and mulching treatments on: yield, fruit quality and water use efficiency of "Anna" apple trees grown in new reclaimed soils. Minufiya J. Agric. Res.,32 (4): 1175-1191.

Molden, D. (1997) Accounting for water use and productivity. SWIM Paper 1. International irrigation Management Institute, Colombo, Sri Lanka.

Muzammil, H., Hamid, M. I. and Ghazanfar, M. U. (2014) Salicylic acid induced resistance in fruits to combat against postharvest pathogens: a review. Archives of Phytopath and Plant Protection. Published online 05 Feb.: 1-9.

Ngullie, C.R., Tank, R.V. and Bhanderi, D.R. (2014) Effect of salicylic acid and humic acid on flowering, fruiting, yield and quality of mango (Mangifera indica L.) cv. 'Kesar'. Advance Research Journal of Crop Improvement 5:136-139.

Novica, V. (1979) Irrigation of agriculture crops. Fac. Agric. Press, Nvia sad, Yugoslavia.

Perez-Perez, J. G., Roble, J. M. and Botia, P. (2009) Influence of deficit irrigation in phase III of fruit growth on fruit quality in 'lane late'sweet orange. Agricultural Water Management, 96 (6), 969-974.

Rahmani, N., Ahlawat, T.R., Kumar, S. and Mohammadi, N. K. (2017) Improving productivity in Mango (Mangifera indica L.) cv. Kesar through foliar sprays of silicon and salicylic acid. International Journal of Chemical Studies 5 (6): 1440-1443

Ranjbaran, E., Sarikhani, H., Bakhshi, D. and Mehrdad, P. (2011) Investigation of Salicylic Acid 
Applicationto Reduce Postharvest Losses in Stored Bidaneh Ghermez Table Grapes. Int. J. Fruit Sci. 11: $430-439$.

Raskin, I. (1992) Role of salicylic acid in plants. Annual Review of Plant Biology, 43 (1), 439-463.

Ritenour M. A., Wardowski, F. W., David, T. and July, P (2002) Effects of water and nutrients on the post-harvest quality and shelf life of citrus. Citrus research and education center. Lake Alfred. Cooperative Extension Service. Institute of Food and Agricultural Science. University of Florida.

Saied, H.H.M. (2011) Insight on the effects of salicylic acid on fruiting of Williams banana. Minia J. of Agric Res. \& Develop., 31 (2): 317-326.

Sartaj, A., Tariq, M., Kashif, S.A., Talat, M. and Amjad, A. (2013). Effect of Different Concentrations of Salicylic Acid on Keeping Quality of Apricot cv. Habi at Ambient Storage. J. Biol Food Sci Res, 2 (6): 62-68.
Shah, J. (2003) The salicylic acid loop in plant defense. Plant Biology, 6: 365-371.

Silva, R. B., De Souza, J. L., Junior, R. A.F., Santos, M.A., Renan Cantalice de Souza, R. C. and Santos, W. M. (2019) Actual evapotranspiration and crop coefficient of sweet orange during the initial development phase in the Rio Largo region, Alagoas. Ciência Rural, 49 (6): 1-7.

Tiwari, S., Lata, C., Chauhan, P. S., Prasad, V. and Prasad, M. (2017) A functional genomic perspective on drought signalling and its crosstalk with phytohormone-mediated signalling pathways in plants. Curr. Genomics, 18: 469-482.

Zaghloul, A. E. and Moursi, E.A. (2017) Effect of Irrigation Scheduling under some Biostimulants Foliar Application for Navel Orange Trees on some Water Relations, Productivity, Fruit Quality and Storability in the North Nile Delta Region. Alexandria Sci. Exchange J., 38 (4): 671-686. 